\title{
BUDUĆNOST PRED NAMA? PRISTUP ODRASTA I POTENCIJAL TRANSFORMACIJE SOCIJALNE POLITIKE
}

\author{
Mirela Matković i Danijel Baturina
}

Level-project j.d.o.o.

Radnička cesta 80, 10000 Zagreb

e-mail: mirela.matkovic1@gmail.com

\begin{abstract}
Sažetak
Suvremene državne politike ograničene su prioritetom ekonomskog rasta za koji se sve više propituje doprinosi li osobnom blagostanju. U stručnim se i javnim raspravama sve češće mogu naći teorije o granicama ekonomskog rasta, s posebnim osvrtom na klimatske promjene. Takve spoznaje oblikuju i nova kretanja na medunarodnoj razini usmjeravajući politike sve više prema ideji održivog razvoja. U domeni socijalne države promišljanja novih smjerova odredena su izazovima koje identificiramo s procesima kao što su: globalizacija, pojava novih socijalnih rizika, visoka financijska opterećenja starih socijalnih programa, Europska unija, strahovi i politička inertnost te podržavanje protueuropskih struja, ali i prioritet politika jedinstvenog tržišta $i$ stabilnosti javnih financija zbog kojih posljedično nedostaje adekvatan odgovor na postojeće izazove socijalne države. Promišljanjem izvan uobičajenih okvira rasta prema onom usmjerenom na održivi razvoj, kako zagovara i pokret odrast, koji u radu predstavljamo, u socijalnoj se politici javlja prostor za razvoj novih strategija i socijalnih inovacija sukladnih s principima odrasta. Cilj je ovog rada sagledati, kroz perspektivu odrasta, potencijalne ideje koje mogu transformirati socijalnu politiku. Rad analizira nekoliko ideja: univerzalni temeljni dohodak, revoluciju skrbi i socijalnu (i solidarnu) ekonomiju. Diskusija se osvrće na načine kako novoformirane ideje i strategije mogu ponuditi rješenja za postojeće izazove s kojima se suvremeno društvo i socijalna politika suoćavaju. Promišljanje odrasta predstavlja prostor za nova rješenja koja mogu potencijalno voditi $k$ održivim socijalnim politikama i podmirivanju ljudskih potreba, na što se u zaključku i osvrćemo.
\end{abstract}

Ključne riječi: odrast, socijalna država, socijalna politika

\section{UVOD}

Društveno blagostanje zajednička je težnja svih ljudi na svijetu. Blagostanje staje nasuprot gladi i beskućništva, siromaštva i nepravde te nudi nadu za sigurniji svijet. Osiguravanje socijalne zaštite i blagostanja za što širi krug građana, uz smanjenje siromaštva osnovni su ciljevi socijalne države (Puljiz, 2008).

No, obično se u javnim i stručnim raspravama pojam blagostanja izjednačava s ekonomskim rastom što je razlog zbog kojega je on jedan od najprioritetnijih ciljeva u politikama država diljem svijeta (Jackson, 2017). Od medija pa sve do političara, ekonomski se rast nudi se kao glavni i jedini smjer kretanja društva koji dovodi do boljitka i društvenog razvoja čineći alternativne načine funkcioniranja društva nezamislivima 
(Van den Bergh, 2009). Ekonomski se rast $^{1}$ smatra važnom varijablom u poboljšanju životnog standarda i smanjenju stope siromaštva kroz povećanje razine zaposlenosti i kreiranja veće potražnje za zaposlenjem, ali i povećanju financijskih mogućnosti države za ostvarivanje vlastitih politika i programa. Ekonomski rast također proizvodi sigurno okruženje za investicijska ulaganja koja dovode do širenja zaposlenja, a koji, smatraju, dovode i do veće razine blagostanja društva (Department for International Development, 2008). ${ }^{2}$ Ekonomski se rast mjeri pomoću bruto domaćeg proizvoda (BDP-a) koji predstavlja vrijednost proizvedenih dobara i usluga određene zemlje unutar jedne godine (Samuelson i Nordhaus, 1992:548), a koristi se za određivanje pozicije ekonomija država u odnosu na druge.

Od 70-ih godina pa sve do danas najprisutnija teorija ekonomskog rasta upravo je ona neoklasična. Neoklasična teorija naglašava važnost liberalizacije tržišta i marginalizacije uloge države kako bi se postigao ekonomski rast. Ekonomski se rast zbog toga percipira kao nezamjenjiv i superioran cilj postavljen visoko iznad drugih vrijednosti kao što su socijalna pravda, ekologija, moral i sl., ugrožavajući kako planet, tako i društvo koje na njemu živi (Plehwe i sur., 2006, prema Lietaert, 2010). No, nove teorije naglašavaju promjene u dinamikama odnosa u društvu koje sve više karakteriziraju mrežne strukture s novim oblicima koordinacije, generiranje znanja te shvaćanje komplementarnosti i ovisnosti ekonomskog djelovanja, kao i sve veća težnja da rad postane zajedničko i socijalno dobro (Fumagalli, 2006; prema Meštrović i Cvijanović, 2007).

Zbog sve veće distance između informacija koje pruža $\mathrm{BDP}^{3} \mathrm{i}$ razine osobnog blagostanja koje stanovnici osjećaju, naglasak mjerenja društvenog razvoja potrebno je prebaciti na osobnu razinu, odnosno napraviti pomak od kvantitete prema kvaliteti (Daly, 2005, prema Frajman Ivković, 2012). Ekonomski će rast u budućnosti biti slab ili će se čak zaustaviti prema nekim procjenama, poput onih Organizacije za ekonomsku suradnju i razvoj (Braconier i sur., 2014). Promjene će u tehnologiji također, vjerojatno donijeti

\footnotetext{
1 Definiranjem ekonomije kao pozitivističke socijalne znanosti, ekonomisti su postali manje zainteresirani za širu svrhu ekonomske aktivnosti posvećujući se više teorijama i modelima njezinog rasta. U skladu s takvim okvirom, ekonomski rast postaje ključnom varijablom koju je potrebno povećavati (Kassiola, 1990, prema Ferguson, 2018).

2 Ekonomski se rast definira kao ekspanzija potencijalnog BDP-a ili porast proizvodnje neke države, a bazira se na nekoliko čimbenika. Prvi su od tih čimbenika prirodni resursi kao što su: nafta, plin, mineralni izvori, obradive površine, vode i šume koji predstavljaju početni faktor u ekonomskom razvoju neke zemlje. Drugi je čimbenik ekonomskog rasta ljudski kapital (Samuelson i Nordhaus, 1992) što je vrlo nejasan pojam. On uključuje formalno obrazovanje, stručne programe obuke, obuke na radu, neformalno obrazovanje odraslih te druge oblike obrazovanja i ulaganja u ljude koji poboljšavaju kvalitetu, vodstvo i produktivnost radne snage (Todaro i Smith, 2006), odnosno obuhvaća sve što proizvodi veću radnu učinkovitost pojedinca i organizacije uključujući tjelesno i mentalno zdravlje i sposobnosti, motiviranost za rad i razvoj i sl. Akumulacija kapitala treći je čimbenik koji utječe na gospodarski rast, a podrazumijeva različita ulaganja koja će kroz duži period biti vraćena poput prijevoza, telekomunikacijskog sustava, tvornica i sl. Tehnološke promjene i inovacije zadnji su kotač gospodarskog razvoja (Samuelson i Nordhaus, 1992).

3 S obzirom na univerzalnost korištenja i ograničenje da BDP bude indikator razvoja ili socijalne dobrobiti, neki autori naglašavaju paradoks BDP-a (Van der Bergh, 2008).
} 
dramatični razvoj u svijetu rada i organizaciji društvenog života. ${ }^{4}$ Pitanje društvenih nejednakosti postavlja se sve češće kao jedno od ključnih u razmatranju budućnosti naših društava (primjerice u Milanović, 2016 i Piketty, 2014).

Iz tih i brojnih drugih razloga u zadnjih se desetak godina sve više razvijaju alternativni pokazatelji društvenog razvoja ${ }^{5}$. Stiglitz i suradnici (2009) tako daju određene smjernice za mjerenje društvenog razvoja iz individualne perspektive. Sustav bi mjerenja trebao obuhvaćati različite dimenzije ljudskog života, a ne samo prosječnu razinu blagostanja, uključujući i objektivnu i subjektivnu perspektivu tog koncepta. Zagovaranje novih mjera i njihovog korištenja te donošenje odluka utemeljenih na podacima koji se dobivaju mjerama zasigurno doprinose stvaranju održivije ekonomije, odnosno ekonomije koja u prvi plan stavlja čovjeka i njegove potrebe, ali i potrebe sljedećih generacija (Coyle, 2011, prema Frajman Ivković, 2012). I drugi autori zagovaraju stavljanje ljudskih potreba u prvi plan (Koch i sur., 2017).

Osim različitog pogleda na mjerenje blagostanja sve je prisutnija tema granica ekonomskog rasta. Prioritet ekonomskog rasta duboko je utjecao na odnose između ljudi i njihove okoline (Lietaert, 2010) uzrokujući klimatske promjene, iskorištavanje prirodnih resursa, kao i brojne druge posljedice. U skladu $s$ time su i upozorenja znanstvenika o magnitudi krize i nužnosti hitnih intervencija (Ripple i sur., 2019). Primjerice, trenutno 13.227 znanstvenika iz 156 zemalja podržava njihove tvrdnje i poziva na akciju (Alliance of World Scientists, 2020). Mnoge organizacije poput UN-a i Europske unije posebnu pozornost pridaju konceptu održivog razvoja te on postaje i dijelom politika EU (primjerice Europske strategije za održivi razvoj) koje ga definiraju kao poboljšanje kvalitete života i blagostanja za sadašnju i buduću generaciju. Unatoč tomu što postoje brojne definicije koje se oslanjaju na važnost pojedinih faktora, prisutan je određeni konsenzus da održivi razvoj obuhvaća tri stupa: ekonomski rast, očuvanje okoliša i socijalni razvoj od kojih novi pristupi poput odrasta koji će se tematizirati ovdje sugeriraju da svaki stup mora biti jednak i održiv. Ovaj kratki i uvelike nepotpuni osvrt na neke od dilema s kojima se susrećemo pri razmatranju trenutnog i budućih smjerova rasta i razvoja poslužit će nam kao uvod u rad kojemu je cilj nasloviti potencijal jednog od alternativnih pristupa rastu i razvoju - „odrast“ i to kroz prizmu mogućeg utjecaja na socijalnu državu koja se i sama trenutno nalazi pred brojnim izazovima.

U sljedećem dijelu teksta najprije ćemo definirati ideju odrasta i njezina ključna obilježja. Kako bi povezali principe odrasta s budućim razvojem socijalne politike prikazat

4 Sad već „čuvena“ studija s Oxforda (Frey i Osborne, 2013) procjenjuje da je oko 47\% ukupne zaposlenosti u SAD-u u kategoriji visokog rizika, tj. da su poslovi za koje se očekuje da bi mogli biti automatizirani relativno brzo, možda tijekom sljedećeg desetljeća ili dva. Studija OECD-a (Nedelkoska i Quintiti, 2018) ukazuje na mogućnost značajnih promjena kao rezultata automatizacije.

5 Indikator stvarnog rasta i indeks održivog ekonomskog blagostanja, indeks sveobuhvatnog bogatstva, indeks ljudskog razvoja, OECD-ov indeks boljeg života, nacionalni indeks sreće, bruto nacionalna sreća, indeks sretnog planeta samo su neki od brojnih metoda mjerenja razvoja koji predstavljaju alternativu bruto domaćem proizvodu (Frajman Ivković, 2012). 
ćemo trenutne izazove koji stoje pred socijalnim državama. Nakon toga ćemo naznačiti neke od ideja pokreta odrast kao mogućih naznaka za rješenje specifičnih izazova socijalne politike. Diskusija će propitati mogućnosti implementacije naznačenih rješenja i u zaključnom dijelu ćemo dati pledoaje o vrijednosti promišljanja novih ideja u socijalnoj politici, ali i društvu generalno, u vidu izazova koji nas čekaju u budućnosti.

\section{ODRAST: PRISTUP I OBILJEŽJA}

Odrast $^{6}$ označava jedan od najbrže rastućih globalnih društvenih pokreta kojim se zagovara drugačiji pristup pretvorbi i upotrebi energije i materijala na Zemlji. Osim tehnološke komponente pokreta, on podrazumijeva i društvene strukture te upravljačke mehanizme koji tu upotrebu usmjeravaju (Domazet i sur., 2014, prema D’Alisa i sur., 2016). Odrast se može definirati kao politički slogan s teoretskim implikacijama (Latouche, 2010:519) kojim se zagovara pravedno smanjenje proizvodnje i potrošnje radi poboljšavanja društvenog blagostanja i ekoloških uvjeta na zemlji. Suprotno od aktualne paradigme koja smatra ekonomski rast uvjetom za razvoj čovječanstva, odrast zagovara upravo suprotno - razvoj čovječanstva bez ekonomskog rasta (Schneider, 2010).

Iako su razmišljanja o ograničenju zemljinih resursa započela prvu fazu razvoja ideje odrasta 70-ih godina, drugi val koji karakterizira kritika ideje održivog razvoja javlja se u prvom desetljeću 21. stoljeća. To razdoblje ishodište je i pokreta odrasta započetog člankom „Održivi odrast“ u čast pionira ekološke ekonomije i bioekonomije Georgesca-Roegena u časopisu Casseurs de pub (2002). Nedugo nakon izdavanja članka, 2008., održana je i prva konferencija u Parizu koja je dovela do kreiranja deklaracije te tako označila i začetak međunarodne istraživačke zajednice usmjerene na temu odrasta (D`Alisa i sur., 2016:5). ${ }^{7}$ Deklaracija zagovara stabiliziranje globalnih i nacionalnih ekonomija kroz: smanjivanje globalnog ekološkog otiska na održivu razinu; davanje

\footnotetext{
6 Pojam odrast prvi se puta javlja u francuskom jeziku pod izrazom Décroissance koji u doslovnom smislu označava silazak, spuštanje, pad. Pojam je prvi put upotrijebio 1972. Andre Gorz postavljajući pitanje koje se i danas nalazi u samom središtu rasprave odrasta - je li ravnoteža zemlje spojiva s razvojem kapitalizma kojeg u svojoj suštini obvezuje kontinuirani rast pa posljedično i iskorištavanje ograničenih resursa (Gorz, 1972, prema D`Alisa i sur., 2016).

7 Iako se razvijao paralelno s disciplinama kao što su ekološka ekonomija i bioekonomija, za širinu razmišljanja o odrastu možemo zahvaliti mnogim različitim strujama misli koje su polazište svojih teorija imale kako u prirodnim, tako i u društvenim znanostima. Struje misli koje su začele ideju odrasta, bioekonomija i ekološka ekonomija utjecale su na razumijevanje granica u iskorištavanju resursa te su se bavile pitanjima zbrinjavanja sve većeg otpada i tako stvorile temelje za razvoj samog pokreta. Uz utjecaj druge struje misli, ekologije i zaštite okoliša, odrast se svrstava u pokret koji zagovara ekološku održivost u društvu budućnosti. Osim u ekološkoj, odrast zagovara promjene i u ekonomskoj sferi društva. Kroz treću struju misli koja je nastala kao kulturno-institucionalna kritika društvenog rasta, odrast je prihvatio kritiku usmjerenu na koncept razvoja shvaćajući ga previše ekonomski orijentiranog. Četvrta struja misli zagovara vraćanje demokratskih procesa u različite segmente društva. Zadnji izvor ideja za odrast usmjeren je na poštivanje svih dimenzija života na zemlji, a obuhvaća uvažavanje drugih pojedinaca i njihove kreativnosti, duhovnosti te prihvaćanje dobrovoljnog minimalizma u odnosu na sveprisutni konzumerizam društva (Schneider, 2010).
} 
dovoljno vremena za njegovo smanjivanje (posebice za zemlje koje imaju značajno veći ekološki otisak od onog održivog); održivo povećanje potrošnje u zemljama s visokim stopama siromaštva kako bi se ostvario adekvatni životni standard i smanjile razine siromaštva; povećanje ekonomske aktivnosti za neka društva uz ravnopravnu redistribuciju prihoda i bogatstva unutar i između država, posebno se osvrćući na izjednačavanje postojećih razlika između bogatih zemalja Prvog svijeta te siromašnih zemalja Trećeg svijeta (Research and Degrowth, 2010). ${ }^{8}$

Definirajući ekonomski rast temeljnim uzrokom socijalnih i ekoloških problema, odrast se postavlja na stranu snažnog zagovaratelja napuštanja prioriteta rasta i s njim povezanih ekonomskih pokazatelja (Sorman i Giampietro, 2013). ${ }^{9}$ Održivi odrast zagovara smanjenje proizvodnje i potrošnje $s$ visokim intenzitetom resursa koje bi posljedično dovelo i do smanjenja BDP-a. Shvaćajući da BDP prikazuje samo mjeru ekonomske aktivnosti koja ne govori o društvenim nejednakostima, dobrobiti ili ekološkoj održivosti, BDP postaje supsidijaran pokazatelj unutar ideje odrasta. Odrast ne podrazumijeva potpunu negaciju rasta, nego smanjivanje rasta samo onih organizacija i aktivnosti koje ne doprinose kreiranju održivog društva. Fokus tako nije na smanjenju ekonomskog rasta ili BDP-a, već na redefiniranju socijalne države te ideje države blagostanja (Schneider, 2010). Zbog svoje tendencije da generira što održivije društvo, odrast $s$ jedne strane obuhvaća teorijsku razinu s misaonom školom i znanstvenim i polemičkim tekstovima, konferencijama kao i usmjerenjima na sveučilištima te $s$ druge strane, praktičnu razinu koja uključuje svjetonazor i razumijevanje stvarnosti drugačije od dominantne ekonomske paradigme te postupanje u skladu s njome. Iako zagovara određene društvene odnose i vrijednosti suprotne onima dominantnima za sadašnje doba, upravo zbog čega se i stvara veliki otpor interesnih skupina, ${ }^{10}$ odrast ne podrazumijeva već unaprijed postavljene i nepromjenjive ciljeve, već nudi otvoreni diskurs za razmjenu ideja i dobrih praksa koje s vremenom mogu biti implementirane u širi kontekst društva (D`Alisa i sur., 2016). Odrast tako čini multidimenzionalni koncept interpretacija današnjeg društva

\footnotetext{
8 Odrast smatra da rješenje za socijalne nejednakosti između Prvih i Trećih zemalja svijeta nije u daljnjem ekonomskom rastu Prvih zemalja i prelijevanja ekonomije na siromašnija područja, već upravo suprotno, jačanje lokalne ekonomije siromašnijih zemalja (Parrique, 2019).

$9 \mathrm{U}$ tom smislu s idejom odrasta povezane su i kritike zagovaratelja rasta. Jedna je od njih teza da ekonomski rast dovodi do bogatstva koje je neophodno za socijalni i ekološki progres, dok u suprotnosti, odrast vodi do recesije (Spangenberg, 2010), odnosno pada produktivnosti i porasta nezaposlenosti. Mirovinski se sustavi također oslanjaju na gospodarski rast kako bi nadoknadili odstupanja u demografskim promjenama, a koji bi u takvom obliku, u slučaju implementacije politika odrasta, bio ugrožen. Osim na to, kritike su usmjerene i na alternativne indikatore rasta pri čemu kao takvi nisu uspjeli zamijeniti BDP kao standardnu mjeru ekonomskog blagostanja (Strunz i Schindler, 2017). Kritike idu i u smjeru da je ideja odrasta tehnofobična, usmjerena protiv razvoja društva, znanosti i inovacija, da je revizija prošlosti, odnosno da je autoritarna (Parrique, 2019).

10 Prvenstveno interesnih skupina koje profitiraju od ekonomskog rasta kao što su: $1-2 \%$ osoba iznad gornje granice dohotka, određene srednje i velike korporacije, korporacije koje se bave fosilnim gorivima te visoko intenzivni emisijski sektor, komercijalne banke i financijski sektor kao i vlast koja bi mogla izgubiti kontrolu nad monetarnom politikom (Parrique, 2019).
} 
i skup preporuka za praktičnu primjenu uvijek otvorenu za javnu raspravu nadajući se pronaći one pravce koji na demokratski način mijenjaju neodrživ sustav današnjice (Schneider, 2010:513).

Osim što nema konsenzus vezan za strategije djelovanja pokreta, u njemu sudjeluju vrlo različiti akteri. Od sindikata, političkih stranka, društvenih pokreta i različitih pojedinaca koji na individualnoj razini sudjeluju u kreiranju novog društva. Svima je zajedničko uvažavanje i zagovaranje vrijednosti dijeljenja, jednostavnosti, konvivijalnosti, skrbi i zajedničkih dobara. Predstavljajući vrlo raznolik broj aktera i njihovih ideja, unutar pokreta odrasta ne postoji jasno definirano jedinstveno stajalište o strategijama djelovanja i transformacije društva ${ }^{11}$ što može predstaviti, ili slabost pokreta, ili pak potencijal za širi razgovor o budućim društvenim promjenama. Od aktivista pa do političkih stranaka i do pojedinaca, u samom pokretu postoji suglasnost da je transformacija rezultat brojnih različitih strategija i aktera koji mijenjaju, kako svakodnevnu, tako i političku razinu (Demaria i sur., 2013, prema D`Alisa i sur., 2016) kako bi ostvarili društvo u kojemu će životni standard biti veći uz manju potrebu za radom i potrošnjom (Latouche, 2009). ${ }^{12}$ U skladu $s$ temeljnim ciljem odrasta da ostvari društvo veće dobrobiti odrast uvelike može pružiti odgovore na izazove s kojima se socijalne države danas suočavaju. Te ćemo izazove naznačiti u sljedećem poglavlju.

\section{IZAZOVI RAZVOJA SOCIJALNIH DRŽAVA ${ }^{13}$}

Socijalna država današnjice uvelike se razlikuje od socijalne države 20. stoljeća. Tradicionalna socijalna država kompenzirala je nedostatke tržišta uglavnom horizontalnim transferima tijekom životnog ciklusa uz rijetke vertikalne transfere siromašnijim skupinama. Obuhvatnoj redistributivnoj ulozi države te povećavanju poreza išao je u prilog kontinuiran i visok ekonomski rast koji je omogućavao širenje razine socijalne zaštite (Taylor-Gooby, 2005). Za razvoj sveobuhvatnih socijalnih politika usmjerenih prema tradicionalnim socijalnim rizicima zaslužna je jaka politička i mobilizacijska moć skupina pogođenih rizicima - radnika. Za razliku od njih, populacija koja je danas ugrožena novim socijalnim rizicima vrlo je heterogena skupina s niskom razinom političke moći i mogućnosti mobilizacije, a globalizirana ekonomija te mjere štednje dodatno pogoršavaju njihov položaj (Bonoli, 2005).

Iako se već nekoliko desetljeća raspravlja o krizi socijalne države uzorkovanoj globalizacijom, starenjem stanovišta, promjenama struktura obitelji ili obrazaca rada (Puljiz,

11 One se tako mogu podijeliti na građansko poslušne i one građansko neposlušne, tj. one koji odbijaju biti u sustavu organizirane vlasti (D`Alisa i sur., 2016:24).

12 Iako neki teoretičari smatraju da društvo koje ne obilježava ekonomski rast može potencijalno zaživjeti unutar kapitalističkog društva (Lawn, 2011), većina se kritičara ekonomskog rasta ipak slaže kako je društvo odrasta nekompatibilno s neoliberalnim kapitalizmom (Blauwhof, 2012; Klitgaard, 2013).

13 Iako mnogi problemi ovise i o geografskom kontekstu, ovdje probleme ponajviše razmatramo u okviru razvoja socijalne države unutar konteksta EU. Kako sve države imaju vlastite tradicije razvoja socijalne politike, ovisnosti o prijeđenom putu i tekuće zadatosti, prikaz dajemo u općenitom obliku. 
2008), danas Hemerijck (2013) navodi glavne izazove koji sudjeluju u transformaciji europskih socijalnih država.

Globalizacija ${ }^{14}$ je prvi izazov. Ona podrazumijeva jačanje međunarodne ekonomske ovisnosti te preseljenje tržišnog natjecanja na međunarodnu razinu. Kako bi se kreirala nova radna mjesta i naposljetku ostvario ekonomski rast, vlade instrumentima različitih politika djeluju na otvaranje ekonomije inozemnim investicijama, liberalizaciji tržišta, smanjenju i stabiliziranju inflacije, privatizaciji, strukturalnim promjenama i štednjama u sustavu socijalne zaštite, a sve u vjeri kako će veći ekonomski rast dovesti do „slijevanja“ ekonomije i na niže klase (Howell, 2006; Glyn, 2006; Busemeyer, 2009, prema Hemerijck, 2013). Drugi izazov predstavljaju promjene u rodnim ulogama u obitelji i tržištu. Prijašnje društvo karakterizirale su snažne rodne podjele poslova. Dok su ženski poslovi uglavnom bili u vezi s kućom i brigom o djeci i starijima, uloga muškarca bila je prehranjivanje obitelji (Bonoli, 2005). U skladu s time bila je i usmjerenost programa socijalne države koji su se temeljili na muškom hranitelju te su pokrivali različite faze života is njima povezane rizike - od faze odrastanja i pasivnih primanja za obitelj, faze obrazovanja te edukacije i treninga za zaposlenje preko stabilnog zaposlenja u industriji i socijalnog osiguranja sve do starosti i mirovine.

Razvoj uslužne ekonomije u zadnjih nekoliko desetljeća praćen je većom razinom fleksibilnosti i nestabilnosti na tržištu rada, povećanja broja ugovora na određeno i razvoja prekarnih poslova. ${ }^{15}$ Dodatni se problem stvara zato što se moderni socijalni programi, ponajviše mirovine, i dalje oslanjaju na tradicionalne oblike tržišta, što s vremenom generira nove socijalne probleme u starijoj dobi (Bonoli, 2005). Događa se i trend polarizacije zaposlenja prema kojemu se stopa zaposlenosti povećala, kako za najviše, tako i za najmanje kvalificirane radnike kreirajući pad u zaposlenosti za srednje kvalificirane radnike (Manning i Salomons, 2009, prema Hemerijck, 2013). Osim razvoja uslužne ekonomije, javljaju se i trendovi demografskih promjena, odnosno starenja stanovništva te promjena u rodnim ulogama, a koji zajedno predstavljaju problem za tradicionalni oblik socijalne države usmjerene na muškog hranitelja (Taylor-Gooby, 2005). Zahvaljujući feminističkoj emancipaciji, širenju obrazovanja, većoj fleksibilnosti rada i većoj mogućnost balansiranja između obiteljskog i radnog života, žene su u samo jednoj generaciji od domaćica postale radnice (Jaumotte, 2003, prema Hemerijck, 2013).

U skladu sa željama žena da prije početka roditeljskog života ostvare i sigurno zaposlenje, a uzimajući u obzir fleksibilnost radnih uvjeta, prekarne poslove i visoku stopu nezapo-

14 Globalizaciju možemo definirati kao progresivan proces integracije ekonomija i društva koji se očituje u tri aspekta: prvi - onaj vezan za jačanje trgovine i ulaganja, razvoj tehnologije, priljeva informacija i komunikacije; drugi - vezan za politike i institucije poput: liberalizacije tržišta rada, javljanja međunarodnih standarda rada te drugih nacionalnih i međunarodnih pravila koje potiču globalizaciju te treći koji se odnosi na socijalnu dimenziju globalizacije, odnosno koje posljedice ostavlja na zapošljavanje, radne uvjete, prihod te socijalnu zaštitu (Međunarodna organizacija rada, 2003).

15 Iako ugovori o radu na određeno mogu biti most prema stabilnom zaposlenju, često se događa da upravo s njima mlađe osobe zaglave u kontinuiranoj nesigurnosti iz koje teško izlaze (Hemerijck, 2013). 
slenosti žena u društvu (Esping-Andersen, 1999, prema Hemerijck, 2013) nije čudno što takve promjene ostavljaju posljedice i na druge sfere društvenog života. Niža je stopa stupanja u brak te se on uspostavlja u životnom razdoblju kasnije nego što se sklapao u prošlosti. Također, veće su stope razvoda braka, smanjuje se stopa nataliteta te se povećava broj samohranih roditelja, što sve zajedno rezultira većom heterogenošću obiteljskih struktura za koje država često vrlo teško pronalazi adekvatna socijalna rješenja. Navedene promjene dovode do novih socijalnih potreba, u vezi s brigom za djecu izvan obitelji te brigom za starije i druge osobe kojima je potrebna skrb koju u suvremenom društvu preuzimaju državne i privatne institucije. Novi problem čine i sve veće migracije stanovnika i razlike u kulturama, a sve veći broj izbjeglica predstavlja i novi pritisak na redistributivnu ulogu socijalne države (Soroka i sur., 2006, prema Hemerijck, 2013). U skladu s navedenim promjenama, definirani su novi socijalni rizici (Bonoli, 2005) koji pogađaju osobe u ranijim fazama života nego oni stari te stvaraju veći problem za marginalizirane skupine koje imaju otežan pristup sustavu obrazovanja i prekvalifikacije ili onima koji nemaju pristup neformalnoj ili formalnoj skrbi (Taylor-Gooby, 2005). Ograničenost reforma socijalne države i visoka financijska opteré́enja tradicionalnih oblika socijalne zaštite treći je izazov koji pogađa socijalnu državu. Izazov je socijalne države održivost sustava zaštite (Esping-Andersen i sur., 2002) u društva koje karakterizira trend sve većeg starenja stanovništva i niske stope fertiliteta te pitanje nedovoljnog broja zaposlenih osoba. Takvi trendovi stvaraju neravnotežu između broja zaposlenih i broja umirovljenih osoba. Starenje stanovništva stvara pritisak i na javne financije, posebice na održivost zdravstvenog i mirovinskog sustava koji je izgrađen na temeljima zlatnog doba socijalne države, te može funkcionirati samo u vremenima visoke stope fertiliteta, pune (muške) zaposlenosti i kontinuiranog ekonomskog rasta (Dang i sur., 2001, prema Hemerijck, 2013). Tome se dodaje i problem skrbi za starije uslijed zaposlenosti oba partnera u obitelji što stavlja pritisak na razvijanje formalnih oblika skrbi. Iako neki smatraju da stari socijalni rizici iza sebe imaju jaku lobističku moć koja onemogućava reforme socijalne države (Pierson, 2001), neke fundamentalne reforme mirovinskog i zdravstvenog sustava ipak su se dogodile. Kao cilj moderne socijalne države postavlja se nužnost usklađivanja, kako starih, tako i novih socijalnih rizika. I dok stari socijalni rizici još imaju široku potporu među javnosti, za javljanje rješenja u obliku politika za nove socijalne rizike izostaje moć skupine da mobilizira svoje snage (Hemerijck, 2013). Četvrti izazov predstavljaju strahovi o silaznoj mobilnosti budućih generacija, politička pasivnost te sirenje podrške desnoj, populističkoj, protuimigrantskoj i protueuropskoj struji. Moderna socijalna država rezultat je kompromisa između socijalnih demokrata, kršćanskih demokratskih stranaka te sindikata nakon Drugog svjetskog rata. Puna zaposlenost i široki raspon socijalne zaštite išli su ruku pod ruku te predstavili zlatno doba socijalne države (Judt, 2007, 2010; Elchardus, 2009, prema Hemerijck, 2013) koje je omogućilo razvoj visokog životnog standarda u zapadnom svijetu. Visoki europski standard i dalje predstavlja težnju većine građana Europske unije, a prioritet paradigme ekonomskog rasta i mjera štednje koje ga podupiru u izravnom je sukobu s njim. U skladu $s$ nezadovoljstvom kretanjem EU javljaju se i sve češći strahovi te jačanje radikalne pro- 
tueuropske desnice (Hemerijck, 2013). Iako je pitanje socijalne države kroz povijest primarno definirano nacionalnom razinom, današnje socijalne sustave uvelike oblikuje kompleksni višerazinski sustav europske socijalne i ekonomske vladavine kreirajući tako socijalnu državu koja nije posve suverena.

Važna uloga Europske unije u redefiniranju modernih modela socijalne države posljednji je izazov. Premda je od začetka Europske unije prepoznata važnost socijalne dimenzije, ona je definirana isključivo kao nadopuna tržištu kroz ostvarivanje visoke zaposlenosti, univerzalnu socijalnu zaštitu i politiku borbe protiv siromaštva. Tome je doprinijela i liberalizacija tržišta te makroekonomska politika integracije s kojom se javlja i neoklasični ekonomski model 80-ih godina (Ferrera, 2005). Donošenjem Ugovora iz Amsterdama 1996. naglašava se potreba za izgradnjom socijalne Europe. Glavni fokus socijalne politike Europe toga doba bila je usmjerenost prema stvaranju veće razine zaposlenosti (Europska komisija, 1994). U tom se kontekstu na tržišno natjecanje prvi puta počelo gledati, ne kao na problem, već kao na sredstvo modernizacije socijalne politike (Blair i Schroeder, 1999, prema Taylor-Gooby, 2005), mijenjajući ulogu socijalne politike od zaštite pojedinaca od tržišta do uloge podržavatelja ekonomske politike kojima je cilj ostvariti veću efikasnost i produktivnost uz povećanje stope zaposlenosti (Europska komisija, 2003). EU zbog toga donosi i Europsku strategiju zapošljavanja i Lisabonsku strategiju (Vijeće EU, 1997) kojoj je cilj modernizirati Europski socijalni model, odnosno do 2010. ostvariti cilj i biti: „najkompetitivnija i najdinamičnija ekonomija utemeljena na znanju, sposobna kreirati održivi rast s više kvalitetnih poslova i s boljom razinom socijalne kohezije" (Europski parlament, 2000:3). ${ }^{16}$

Nova faza započela je 2010. definiranjem strategije Europa 2020. Europskom strategijom za pametan, održiv i uključiv rast potvrđen je novi smjer kretanja europske socijalne politike koji naglašava kombinaciju ekonomskog rasta, socijalne i ekološke održivosti, a napredak u ostvarivanju ciljeva potiče se i prati u okviru Europskog semestra (Armstrong, 2012). Premda se Europskim semestrom nudi mogućnost većeg usmjeravanja pažnje na socijalne ciljeve (Zeitlin i Vanhercke, 2017, prema Verdun i Zetilin, 2018), mnogo autora smatra da ono favorizira ekonomske ciljeve u odnosu na one socijalne (Copeland i Daly, 2015; Crespy i Menz 2015; de la Porte i Heins 2015, prema Verdun i Zetilin, 2018) stavljajući naglasak na ekonomska pitanja štiteći ih „tvrdim“ zakonima. Unatoč prioritetu i naglasku ekonomske dimenzije u socijalnim pitanjima, vidljive su i neke nove inicijative na europskoj razini koje zagovaraju veću važnost socijalnih vrijednosti. Primjer je donošenje Europskog stupa socijalnih prava koji čini skup prava i principa koji se mogu razumjeti kao agenda ili proces usmjeren prema većem značenju socijalnih vrijednosti te iako pokazuje određenu razinu volje, nema obvezujućih instrumenata te malo znači za Europsku socijalnu državu (Garben, 2018).

16 Kako bi ostvarili taj cilj počinju se primjenjivati meki instrumenti koordinacije politika između zemalja EU. U početku usmjereni prema području zapošljavanja, kasnije se takvi instrumenti šire i na područje socijalne isključenosti dobivajući time model otvorene koordinacije (Ferrera i sur., 2004). 
Još jedan važan dokument koji državama članicama daje smjernice za modernizaciju socijalne države u smjeru strategije Europe 2020 jest paket socijalnog ulaganja (Europska komisija, 2013). Paket socijalnog ulaganja obuhvaća preporuke državama za efikasno i efektivno korištenje proračuna u ostvarivanju održive socijalne zaštite i investiranja u djecu i mlađe osobe te nastoji osnažiti sadašnje i buduće ljudske kapacitete, unaprijediti mogućnosti participacije na tržištu te tako omogućiti pozitivnije socijalne ishode uz naglasak na preventivne mjere i smanjenje potrebe za socijalnim naknadama (Europska komisija, 2019a). Koncept socijalnih ulaganja, koji se zagovora u Paketu, uključuje dvostruki cilj: modernizaciju socijalne države kako bi efikasnije rješavala probleme novih socijalnih rizika te osiguranje financijske i političke održivosti socijalne države. Programi socijalnih ulaganja podrazumijevaju programe ulaganja u ljude kojim se jačaju kapaciteti pojedinca za suočavanje sa životnim rizicima, a kako bi na produktivan način mogli sudjelovati u ekonomskoj dimenziji društva, ali i društvu u cjelini (Babić i Baturina, 2016).

Što se tiče ishoda socijalne politike, iako se Lisabonskom strategijom EU usmjerila na smanjenje razine siromaštva, ekonomski rast, kreiranje novih poslova i socijalnu koheziju one se u praksi nisu pokazali kao kategorije koje pospješuju simultani razvoj (Cantillon, 2010). Veći fokus na zaposlenost, uz veće troškove zdravstvenog i mirovinskog sustava uzrokovanih demografskim promjenama (Vandenbroucke i Vleminckx, 2011) doprinio je smanjivanju naknada za najugroženije skupine i pooštravanju uvjeta za njihovo ostvarivanje, dok su od razvoja politika usmjerenih na povećanje isplativosti rada korist imale samo više prihodovne grupe. Povisivanjem stope zaposlenosti samo su djelomično profitirala kućanstva s niskim intenzitetom rada - dok se broj kućanstva $s$ visokim intenzitetom rada povećao (Cantillon, 2010), broj kućanstva s nultim intenzitetom ostao je isti, unatoč porastu stope zaposlenosti u godinama prije krize (Social Protection Committee, 2009).

Stoga, usmjerenje politika EU prema većoj važnosti socijalne Europe ne djeluje obećavajuće. Zagovara se smanjenje državnih intervencija s većom ulogom slobodnog tržišta i privatizacijom socijalnih usluga (Taylor-Gooby i sur., 2017). Prepoznatljivost socijalnih problema povećava se, no promjena u smjeru jačanja europske socijalne države ograničena je s obzirom na prioritet ostvarivanja cilja povećanja konkurentnosti na tržištu. Uzimajući u obzir sve veće nezadovoljstvo koje se javlja među stanovništvom te prijeteće klimatske promjene i sve sporiji ekonomski rast, kao i sve jače propitivanje uloge socijalne politike, ali i ekonomije u društvu, upitno je na kakvu će se politiku buduća vladavina EU usmjeriti te hoće li doći do pomaka prema održivoj socijalnoj politici (Hirvilammi i Koch, 2020). Nedavna je ekonomska kriza dodatno potaknula pitanje učinkovitijeg organiziranja i djelovanja socijalne države u podmirivanju socijalnih potreba društvenih skupina pogođenih socijalnim rizicima. Stoga valja propitivati moguće alternative. Sukladno tome usmjeriti ćemo se na ideje odrasta koje je potencijalno moguće implementirati na razini Europske unije, a koje mogu djelovati na suočavanje s novim socijalnim rizicima i rješavanju pojedinih društvenih izazova. 


\section{IDEJE ODRASTA U TRANSFORMACIJI SOCIJALNE POLITIKE}

U ovom poglavlju predstavit ćemo ukratko neke od ideja koje se pojavljuju recentno i bliske su pristupima odrasta, a odnosit će se na univerzalni temeljni dohodak, revoluciju skrbi te socijalnu i solidarnu ekonomiju.

\subsection{Univerzalni temeljni dohodak}

Univerzalni temeljni dohodak ${ }^{17}$, u daljnjem tekstu UTD predstavlja dohodak koji strane političke zajednice plaćaju svim svojim članovima na individualnoj osnovi bez provjere imovinskog cenzusa ili nužnosti rada (Van Parjis, 2006, prema McGahey, 2018). Zagovaratelji odrasta dodaju i četvrto pravilo prema kojemu UTD mora biti toliko visok da može podmirivati egzistencijalne potrebe osobe te omogućavati participaciju u društvu. Dohodak podrazumijeva novčano davanje koje se isplaćuje periodično (npr. mjesečno), a prema odrastu može uz novčana davanja obuhvaćati i druge besplatne usluge koje ostvaruju podmirenje osnovnih potreba ili osiguravaju participaciju u društvu (Blaschke, 2017). ${ }^{18}$ Prema ideji odrasta, UTD se zagovara kao zagarantirano pravo svake rođene osobe, od trenutka rođenja pa sve do smrti, neovisno o postojanju poslovne sposobnosti (Blaschke, 2017). ${ }^{19}$

UTD također nije uvjetovan radnom prošlosti, statusom ili imovinskim cenzusom, već predstavlja univerzalni program koji pokriva sve skupine društva (McGahey, 2018). Prema odrastu, UTD ne označava isključivo monetarnu mjeru, već primarno princip prema kojemu sve osobe imaju pravo na besplatan i neuvjetovan pristup resursima koji su neophodni za život i participaciju u društvenim procesima (Blaschke, 2017). ${ }^{20}$ Iako se Svjet-

17 Možemo razlikovati dva različita oblika UTD-a. Prvi od njih negativni je porez na dohodak (u daljnjem tekstu NPD) koji je često u vezi s libertarijanskom strujom misli. NPD-om se nastoje zamijeniti svi programi socijalne zaštite, a kako bi se u konačnici smanjili i programi socijalne države (McGahey, 2018). Pravo na negativni porez na dohodak ostvaruju osobe ispod definirane razine imovinskog cenzusa, dok se sredstva za podmirenje NPD-a ostvaruju putem različitih razina oporezivanja ovisnih o razini prihoda osobe. Druga varijanta UTD-a ona je u kojoj se ne ugrožavaju drugi programi socijalne države već UTD postaje nadopuna za njih pružajući građanima umjerenu razinu dohotka (McGahey, 2018).

18 Mjera može biti vezana za određene ekonomske pokazatelje, primjerice indeks cijena ili BDP per capita kako bi bila što više usklađena s društvenim kretanjima (Van Parijs i Vanderborght, 2017).

19 Prema Van Parijs i Vanderborght (2017) UTD ne bi trebao biti ograničen statusom državljanstva, već plaćanjem poreza što bi ujedno isključivalo turiste, neevidentirane migrante, diplomate i zaposlenike međunarodnih organizacija iz tog programa.

20 Prema izračunu Svjetske banke trošak implementacije UTD-a na prosječnoj razini postojećih socijalnih davanja za odrasle osobe iznosio bi 9,6\% BDP-a za siromašne zemlje, 5,1\% za srednje bogate zemlje te $3,5 \%$ za najbogatije zemlje (Svjetsa banka, 2019). Ukoliko bi mjesečni iznos za pojedinca na razini EU27 bio postavljen na 154 eura, ukupni bi novčani trošak implementacije ideje iznosio 608 milijardi eura, odnosno činio bi 0,44\% BDP-a primjerice Njemačke ili 3,08\% BDP-a Slovenije. Implementacija ovakvog modela UTD-a bila bi moguća bez drugih reforma socijalne države uz postavljanje poreza na prihod na $45 \%$ što, prema Mencingeru predstavlja realno ostvariv i preporučljiv cilj prema kojemu se EU treba usmjeriti (Mencinger, 2015). No, izračun Mencingera ne podrazumijeva uštede koje se ostvaruju reformama i promjenama koje nastaju kao posljedica implementacije UTD-a (Mencinger, 2015). Zbog njih, izvjesne 
ska mreža za univerzalni dohodak (BIEN) formalno ne pozicionira između tih varijanata UTD-a, većina tekstova ipak naginje varijanti UTD-a kao dodatku postojećim programima socijalne države (McGahey, 2018), baš kao što se zalaže i sam odrast (Blaschke, 2017). Glavne kritike protiv UTD-a uglavnom se vežu uz visoke troškove i pad motiviranosti za rad uslijed njegove implementacije. Postavljanje smislene razine dohotka UTD-a predstavljalo bi visok trošak uz nužnost pronalaska novih oblika oporezivanja ili drugih izvora javnih sredstava uz mogući negativni utjecaj na javni dug (McGahey, 2018).

Što se tiče kritike pada motivacije za radom, ne postoji jednoglasno slaganje. Tako imamo podijeljena mišljenja da bi postavljanje UTD-a moglo dovesti do smanjenja količine radnih sati, povećanja razine plaća i smanjenja razine produktivnosti u skladu s teorijama ekonomije rada (Ben-Shalom i sur., 2012, prema McGahey, 2018) ili bi pak implementacija UTD-a malo ili nikako djelovala na radnu motivaciju, što potvrđuje eksperiment u Kanadskoj pokrajini Monitobi (Forget, 2015). S druge strane, zbog veće količine dostupnosti novca, neki kritičari naglašavaju mogućnost nastanka inflacije. No, zagovaratelji ideje naglašavaju njegovu važnost pri tehnološkim promjenama jer UTD proizvodi veću ravnotežu u moći između rada i kapitala pogodujući slabo plaćenim radnicima te pritišćući poslodavce na kompromise prema sindikatu u pogledu boljih plaća, smanjenja radnog vremena i poboljšanja radnih uvjeta (Wright, 2002).

Univerzalni programi zaštite pokazuju se boljima jer ciljanije pogađaju najugroženije skupine koje u suprotnom često ostaju bez ostvarenih prava na zaštitu, bilo zbog neznanja, srama ili nečeg trećeg. Uz izbjegavanje nepotrebne birokracije i smanjenje stigmatizacije UTD može postići puno u pogledu siromaštva koristeći vrlo niske ili gotovo nikakve troškove informiranja o samoj mjeri. Univerzalnost ove mjere pogoduje i široj razini prihvaćenosti, ali i potpore pošto se oporezovana sredstva u jednakoj mjeri vraćaju ljudima kao prihod (McGahey, 2018). Važnost UTD-a nije samo u oslobađanju ljudi od nedostatka novaca, već i u nuđenju izlaska iz zamke socijalnih naknada.

\subsection{Formalni i neformalni sektor skrbi i revolucija skrbi}

Skrb može biti usmjerena na sebe i ljude oko sebe, uključujući prijatelje, rodbinu, susjede ili djecu, bolesne, starije, osobe s invaliditetom te druge osobe kojima je specifična skrb potrebna. Skrb može biti plaćena ili neplaćena aktivnost te može trajati kratko ili duže vrijeme (Međunarodna organizacija rada, 2018). U Europskoj uniji 17,6\% populacije EU starije od 15 godina čine osobe s invaliditetom, od kojih oko trećina treba neki oblik tuđe pomoći. U toj se kategoriji najviše nalaze osobe starije od 65 godina kojih će $s$ vremenom zbog demografskih kretanja biti sve više (Eurostat, 2019a). Dodajući tome

\footnotetext{
su značajne uštede povećanjem efikasnosti samog sustava, odnosno smanjenjem troškova administracije, informiranja, nadziranja i sankcioniranja. Prelaskom na elektronski oblik plaćanja ukinula bi se široka birokracija te bi takva davanja bila manje sklona klijentelističkom povlašćivanju, lobiranju ili pak lošoj redistribuciji sredstava. Dodatna se sredstva mogu ostvariti i novim načinima oporezivanja prema razini ostvarenih prihoda, kojima bi se moglo ostvariti potpuno samofinanciranje. Tako bi osobe koje ostvaruju veće totalne prihode plaćale više, dok bi osobe koje ostvaruju manji totalni prihod plaćale manje poreze proporcionalno izračunu koji je potreban za pokrivanje troškova UTD-a (Mencinger, 2015).
} 
oko 79 milijuna djece dolazimo do vrlo velikog broja osoba kojima je potrebna svakodnevna skrb (Eurostat, 2015). Iz toga je razloga pitanje skrbi jedno od važnijih socijalnih pitanja na razini EU.

Cilj je reformi skrbi postizanje efikasnijeg korištenja društvenih resursa promovirajući mogućnost izbora među građanima (Anttonen i Haïkïö, 2011). Smatra se da će se davanjem mogućnosti većeg izbora postići osnaženiji pojedinci i kvalitetnije usluge uz snižavanje troškova usluga, ali i države (Blank, 2000; Greener, 2008, prema Brennan i sur., 2012). Teškoće u balansiranju radnog, plaćenog i obiteljskog života za neke ljude znači i borbu za održavanje vlastite egzistencije, dok za druge toliku razinu iscrpljenosti koja im onemogućuje skrb za bliske osobe u onoj mjeri koju bi oni voljeli. Primjerice, svaki treći stanovnik EU-a u dobi 15-64 godine ima nekoga za koga treba skrbiti (Eurostat, 2019b). Europska komisija u ažuriranoj verziji Zajedničkog izvješća o sustavima zdravstvene zaštite i dugotrajne skrbi i fiskalnoj održivosti (Europska komisija, 2019b) navodi da je neophodno povećati učinkovitost zdravstva i dugotrajne skrbi, ali i osigurati pristup kvalitetnim uslugama sa ciljem poboljšanja zdravlja stanovništva. Zbog potrebe za smanjenjem troškova države smanjuje se i kvaliteta samih usluga, a na udaru su sve dimenzije skrbi koje pruža država, od zdravstva, obrazovanja pa sve do socijalne skrbi. Pošto su u sektorima skrbi najviše zaposlene upravo žene, možemo reći da su upravo one skupina najgore pogođena posljedicama koje ova paradigma ostavlja na taj sektor (Neumann i Winker, 2016).

Pokret revolucije skrbi čini mogući dio odgovora na ove probleme. Revolucija skrbi čini jedan od pokreta unutar ideje odrasta koji zagovara društvo u kojemu će potrebe svih ljudi biti podmirene bez isključivanja ili izrabljivanja drugih. Revolucija skrbi za svoje polazište uzima feminističku kritiku i status skrbi u društvenom životu, a obuhvaća niz različitih organizacija koje se bave problemima njegovateljstva, invaliditeta, roditeljstva, imigranata, različitih sindikata u područjima skrbi i brige za djecu te drugih inicijativa koje podrazumijevaju borbu protiv klasičnog, patrijarhalnog sustava. Premda su neki oblici skrbi plaćeni, poput socijalnog rada, predškolskog odgoja i sl., ipak se većina ove dimenzije odvija unutar obitelji te se ne podrazumijeva radom niti je plaćena (Neumann i Winker, 2016). Ono što revolucija skrbi zagovara jest organiziranje i realiziranje skrbi u neformalnom i formalnom okruženju u skladu s vrijednostima empatije i solidarnosti te demokratskim procesima u područjima odlučivanja, odnosno organiziranje: dostatnog prihoda koji će pokriti troškove života, dostatno slobodno vrijeme kako bi se osobe mogle brinuti o sebi i drugima uz plaćeni rad i slobodno vrijeme za odmor, uključenost u donošenje odluka i jačanje demokratskih procesa u sektoru skrbi, što podrazumijeva novi oblik organizacije institucija koje pružaju skrb u kojemu treba prevladavati veća razina komunikacije između različitih aktera uključenih u proces skrbi, tolerantno društvo koje ne isključuje i ne diskriminira (Winker, 2015), što bi značilo šire reforme socijalne politike. Također se podrazumijevaju značajne promijene „orodnjenog rada“ u kojem rodne podjele na tržištu rada postoje po uzoru na odijeljene rodne uloge u obitelji i kućanstvu (Galić, 2011) te važnost usklađivanja obiteljskih obaveza i tržišta rada s naglaskom na ravnopravnost spolova. Daljnje i značajne promjene rodnih uloga na tržištu rada i u obitelji koje se već dijelom događaju (Oláh i sur., 2018) preduvjet su tome. 
U smislu socijalne države to bi značilo da država mora biti odgovorna za pristup ljudskim pravima. Država treba pružati univerzalne usluge skrbi dostupne svima. Takve usluge bile bi financirane i dizajnirane prema prepoznatim potrebama, a važna je uloga stanovništva i u donošenju odluka u vezi s pitanjima skrbi te demokratizacija institucija skrbi. Zaštita države je potrebna i prilikom zaposlenja koje bi trebalo uključivati pravedne prihode, sigurnost, mogućnost jačanja kapaciteta i socijalnu zaštitu koja bi osobama uvelike olakšavala skrb za sebe i bližnje (Womankind Worldwide, 2019).

Cilj revolucije skrbi zapravo je društvo temeljeno na solidarnosti u kojemu je ono usmjereno na potrebe svih ljudi, neovisno koliko one različite mogu biti. U ovom pogledu revolucija se skrbi dijelom uklapa u opisani koncept socijalnih ulaganja. No, ona podrazumijeva i razvoj kvalitete i opsega onih usluga socijalne države koje utječu na daljnji razvoj čovjeka, njegovu produktivnost i inovativnost te zagovaranje odbacivanja trenutačne paradigme u kojoj se ljudi ne prepoznaju kao socijalna bića. U svojoj biti ona podrazumijeva prebacivanje fokusa s ekonomskih pokazatelja na one više socijalne kreirajući društvo solidarnosti u kojemu su potrebe ljudi ispred ostvarivanja profita i ekonomskog rasta (Neumann i Winker, 2016). Iako su ovakve ideje daleko od implementacije, one se dotiču nekih već naglašenih slabosti socijalne države u skrbi, ali su i bliske nekim trendovima koji se već pojavljuju u socijalnoj politici. Primjerice, kombinirana socijalna politika (engl. welfare mix) označava sustav u kojem vlada, lokalne vlasti, organizacije civilnog društva, trgovačka društva (profitni sektor), obitelj (neformalni sektor) te drugi dionici djeluju umjesto ranijega monopolskog položaja države (Bežovan, 2008). Ona se uvelike temelji na kritici dominantne uloge države i njezinih ustanova u pružanju socijalnih usluga (Bežovan i Zrinščak, 2001) te kao alternativa naglašava važnu ulogu trećeg sektora. Su-kreacija (engl. co-creation) podrazumijeva aktivno uključivanje ljudi koji su izravno povezani s problemom, mjestom ili procesom u različite faze razvoja rješenja (Voorberg i sur., 2015). Su-proizvođenje (engl. co-production) dodaje dimenziju aktivnog građanstva i socijalnog kapitala u usluge koje se razvijaju i pružaju. Obično se odnosi na doprinos samih korisnika uslugama u pružanju, poboljšanju kvalitete i / ili kvantitete usluga, tj. suradnja građana i profesionalaca $s$ namjerom poboljšanja resursa i dobara kako bi zajednički doprinijeli postizanju boljih ishoda i veće efektivnosti (Bovaird i sur., 2015). Ključni je naglasak na partnerstvu, promjeni uloge stručnjaka te sagledavanja i korisnika kao stručnjaka. Su-proizvodnja može dovesti do boljih rezultata kao što su smanjenja troškova pružanja usluga, povećanja zadovoljstva uslugama putem personaliziranih usluga te stvaranjem kapaciteta za suočavanje sa složenim društvenim problemima (OECD, 2011). S druge strane imamo trend personalizacije koji prepoznaje potrebu da se ljudi stavljaju u fokus vlastite skrbi (Social Care Institute for Excellence, 2012). On odražava logiku stavljanja ljudi i njihovih potreba na prvo mjesto te uključuje aspekte osnaživanja osoba da identificiraju vlastite potrebe, kao i proširivanje mogućnosti izbora i kontrole skrbi ili podrškom koju dobivaju građani, posebno oni u nepovoljnom položaju. Duffy (2010) sugerira da bi personalizacija mogla biti korak naprijed u transformaciji socijalne države od paternalističkog modela pružanja socijalnih usluga koji tretira ljude kao korisnike usluga prema modelu koji tretira ljude kao građane. 


\subsection{Suradnja i novi putevi do blagostanja: socijalna i (solidarna) ekonomija}

Ideja odrasta nudi mogućnost implementacije vrijednosti solidarnosti unutar koncepta tržišta, a koje će putem inovativnosti, novih tehnoloških rješenja, znanja i vještina pospješiti rješavanje gorućih problema društva (poput siromaštva ili zagađenja okoliša putem implementacije socijalno solidarnih rješenja u ekonomiji) (Matsui i Ikemoto, 2015). Stoga je bliska socijalnoj (i solidarnoj) ekonomiji i poduzetništvu, ${ }^{21}$ čije se inicijative već značajno pojavljuju na Europskom prostoru, a čije ćemo karakteristike ovdje opisati kako bismo naznačili određenu sukladnost $s$ idejama odrasta.

Procjenjuje se da na razini EU postoji oko 2,8 milijuna subjekata i poduzeća socijalne ekonomije, odnosno 232 milijuna članova zadruga, uzajamnih društava i sličnih subjekata što uključuje 19,1 milijuna radnika diljem EU (Europski gospodarski i socijalni odbor, 2017:22). Prema Social Economy Europe (Poirer, 2014), organizaciji koja promiče socijalnu ekonomiju na razini Europe, socijalna se ekonomija razlikuje od one tradicionalne po nekoliko principa: prioritet socijalnih i individualnih ciljeva nasuprot ostvarivanja dodatnog kapitala, demokratska kontrola koju provode članovi organizacije, kombinacija interesa članova, korisnika i šire zajednice, zajednička odgovornost i solidarnost svih uključenih u proces, reinvesticija viška prihoda prema održivim ciljevima ili razvoju novih usluga korisnih za članove i zajednicu, otvoreno i dobrovoljno članstvo te autonomija koju jamči država.

Za razliku od pojma socijalne ekonomije, solidarna ekonomija nešto je novijeg datuma te obuhvaća stavljanje ljudi u centar ekonomskog i socijalnog razvoja uz vrijednosti poput kooperacije, kolektivnog dijeljenja i akcije. Uzimajući u obzir različite definicije socijalne ekonomije koje se razlikuju ovisno o govornom području, odnosno o samoj

\footnotetext{
21 Potrebno je kratko definirati što podrazumijevamo pod socijalnom ekonomijom. Socijalna ekonomija obuhvaća široku paletu poduzeća i organizacija koje proizvode robu i usluge s izraženim ciljem maksimiziranja socijalnog, ekološkog ili kulturnog utjecaja (Neamtan, 2009). Najnovije konceptualno određenje socijalne ekonomije učinile su njezine vlastite organizacije u Povelji načela socijalne ekonomije (Chaves i Monzón, 2012). Prema Povelji socijalna je ekonomija ona kod koje se pojedinac i socijalni cilj stavljaju ispred profita, koja uključuje dobrovoljno i otvoreno članstvo, demokratsku kontrolu koju provode članovi, kombinaciju interesa članova, korisnika i općeg interesa, zaštitu i primjenu načela solidarnosti i odgovornosti, autonomno upravljanje i nezavisnost od javnih tijela te upotrebljavanje većine troškova za postizanje ciljeva održivog razvoja, odnosno usluga u interesu članova ili općem interesu (Europski gospodarski i socijalni odbor, 2017).

Blizak koncept je i socijalno poduzetništvo koji obuhvaća organizacije koje obavljaju društvenu ili drugu svrhu orijentiranu prema okolišu kroz tržišno poslovanje te pokrivaju sve ili znatan dio svojih troškova putem prodaje na tržišstu (Bornstein, 2004; Borzaga i Defourny, 2001; Defourny i Nyssens, 2010). te spadaju u koncept socijalne ekonomije (Europski gospodarski i socijalni odbor, 2017).

Solidarna je ekonomija ili ekonomija solidarnosti koncept nastao 80 -ih godina u Francuskoj. Smatra se da se gospodarstvo ne može opisati samo kroz tržišnu i novčanu dimenziju, već podrazumijeva tržište, državu i uzajamnost koji se zajedno povezuju kako bi stvorili konkretne inicijative ekonomije solidarnosti. Uz taj koncept, zastupljen je i koncept ekonomije solidarnosti nastao u Latinskoj Americi, a koji vidi ekonomiju solidarnosti kao pokretača društvene promjene prema alternativnom društvu u odnosu na današnji neoliberalni kapitalizam (Europski gospodarski i socijalni odbor, 2017).
} 
percepciji govornika, unutar se ideje odrasta najčešće zagovara ideja socijalne solidarne ekonomije kao kombinacije socijalne i solidarne ekonomije, odnosno vraćanja vrijednosti solidarnosti unutar ideje socijalne ekonomije. Temeljem toga socijalna solidarna ekonomija zagovara promjenu cjelokupnog socijalnog i ekonomskog sustava predstavljajući drugačiju paradigmu razvoja koja podržava karakteristike solidarne ekonomije. Socijalna solidarna ekonomija zagovara promjenu prioriteta od maksimiziranja privatnog profita i ekonomskog rasta prema održivijim prioritetima s ljudima i okolišem u središtu diskusije (Poirer, 2014). Slično, neki autori (Noruzi, i sur., 2010:5) socijalno poduzetništvo sagledavaju kao praksu odgovora na neuspjehe tržišta s transformativnim i financijski održivim inovacijama koje ciljaju na rješavanje socijalnih problema. Faktori koji su djelovali i stvorili određenu potražnju za socijalnim poduzetništvom su ekološke krize i krize u zdravstvu, povećana ekonomska nejednakost, neučinkovitost država u pružanju javnih usluga, povlačenje država u susretu s ideologijom slobodnog tržišta, povećana uloga civilnog društva te natjecanje za resurse (Nicholls, 2006:2). Socijalno poduzetništvo nije više marginalna aktivnost nego postaje nositelj društvene promjene i ubrzano se razvija u autonomno polje istraživanja i prakse.

Socijalna ekonomija nije samo nametnula svoju sposobnost da značajno doprinosi razrješavanju novih socijalnih problema, već je i osnažila svoju poziciju kao institucija nužna za stabilan i održiv gospodarski rast, usklađujući usluge s potrebama, povećavajući vrijednost gospodarskih aktivnosti koje služe socijalnim potrebama, pravednijoj raspodjeli dohotka i bogatstva, ispravljajući neravnoteže tržišta rada i ukratko, produbljujući i osnažujući ekonomsku demokraciju (Monzón i Chaves, 2010). Poduzeća socijalne ekonomije mogu doprinijeti stvaranju novih radnih mjesta, stvaranju novih usluga, regionalnom i lokalnom razvoju te brizi za okoliš. Ona predstavljaju oblik razvoja poduzetništva koji stavlja društvene, ekološke i kulturne misije u središte procesa stvaranja bogatstva (Neamtan, 2009). Organizacije socijalne solidarne ekonomije često stvaraju povezanost $s$ različitim socijalnim pokretima koji se bore za socijalnu i ekonomsku pravdu poput ekoloških pokreta, pokreta protiv siromaštva, pokreta za male seljake, pokreta za zapošljavanje žena ili pak pokreta za reformu zemlje (RIPESS, 2015). U obliku politika usmjerenih na socijalnu državu, socijalna ekonomija davala bi prednost socijalnim ciljevima u odnosu na one ekonomske, implementirajući alternativne metode mjerenja razvoja te potičući poslovne modele prema više socijalnim ciljevima kombinirajući socijalna poduzeća, udruge koje posluju na tržištu kako bi ostvarile ciljeve te socijalne zadruge. Socijalna solidarna ekonomija ide dalje od klasičnog koncepta socijalnih investicija usmjerenih na povećanje zaposlenosti i produktivnosti društva te predstavlja zaokret prema novoj paradigmi usmjerenoj prema solidarnijem i pravednijem društvu (RIPESS, 2015).

\section{DISKUSIJA: U POTRAZI ZA NOVIM RJEŠENJIMA}

Odrast je ideja koja zagovara temeljnu promjenu paradigme socijalnih vrijednosti. Promjena vrijednosti u društvenoj sferi mogla bi biti rješenje i za aktualne izazove socijalne države. Univerzalni temeljni dohodak tako bi mogao biti rješenje za ublažavanje posljedica 
siromaštva i socijalnih nejednakosti uzrokovanih težnjom za konkurentnijom i efikasnijom nacionalnom državom. Time bi se kreirale ravnopravnije startne pozicije različitih skupina u društvu. $S$ druge strane, UTD bi mogao biti i dio odgovora na izazove nekih socijalnih rizika poput prekarnog rada, nedovoljne socijalne zaštite, niske kvalificiranosti i visoke razine ispadanja iz sustava obrazovanja putem zaštite koju pruža. Pojedinci bi imali više mogućnosti izbora kako oblikovati svoj život. UTD bi djelomično mogao odgovoriti i na problem starenja stanovništva i neusklađenosti između obiteljskog i radnog života. Kako bi UTD osiguravao određenu razinu zaštite stanovništva, pojedinci bi imali mogućnosti usmjeriti se i na neplaćene, ali one djelatnosti koje ih ispunjavaju zadovoljstvom, poput skrbi, volonterstva, političkog angažmana ili drugih za društvo korisnih aktivnosti bez ugrožavanja egzistencijalne razine osoba koje se za to odluče.

U tome bi pomogla i revolucija skrbi koja zagovara pružanje kvalitetnijih usluga za te skupine. Ciljajući na univerzalnu pokrivenost uslugama, poboljšanje uvjeta rada u sektoru skrbi te poboljšanje dostupnosti, pristupačnosti te kvalitete skrbi za korisnike, posebne prilagodbe i posebno krojenu socijalnu zaštitu za osobe koje brinu o drugim ljudima, dostatno slobodno vrijeme za brigu o sebi i drugima oko sebe te postojanje adekvatnog slobodnog odmora, revolucija skrbi pružila bi dio mogućih odgovora za socijalne rizike koji se tiču usklađivanje obiteljskih obaveza i plaćenog rada kao i izazove vezane za osiguravanje skrbi, posebice dugotrajne.

Dio odgovora bi također mogla biti socijalna i solidarna ekonomija stvarajući nova radna mjesta za dugoročno nezaposlene osobe te druge marginalizirane osobe kombinirajući nova znanja i tehnologije kako bi se riješili specifični društveni problemi. No, socijalna solidarna ekonomija ide korak dalje od novih socijalnih rizika te podrazumijeva podmirivanje i drugih u manjoj mjeri prepoznatih potreba unutar lokalne zajednice prevenirajući moguće probleme te rješavajući frustracije stanovnika na konstruktivan način.

Kako ima pozitivne implikacije potencijalnih odgovora na nove socijalne rizike, ideja odrasta sve se više širi, a na njezino jačanje i implementaciju mogu utjecati i skupine najviše pogođene njima. Upravo bi njihova mobilizacija mogla dovesti do promjene paradigme, baš kao što je i mobilizacija skupina pogođena tradicionalnim rizicima ranije u povijesti dovela do razvoja socijalne države. No, treba naglasiti da su ovi pristupi tek dijelom isprobani u praksi. UTD je isproban tek u nekim parcijalnim ili bliskim eksperimentima, primjerice u Finskoj (Kangas i sur., 2019) ili pak u Keniji (Egger i sur., 2019) te je dao dijelom obećavajuće rezultate. Revolucija skrbi čini se održivijom u kontekstu manjih zajednica i može funkcionirati tek u izrazito promijenjenoj socijalno politici i društvu dok se sadašnji pristupi više oslanjaju na dualizam institucionalnih usluga koje je razvila socijalna država i neformalne skrbi u obitelji. Socijalna i solidarna ekonomija jača u EU (Europska komisija, 2014; CIRIEC, 2017), no iako pokazuje potencijal kombiniranja ekonomske i socijalne logike, ali i pomoć najranjivijim skupinama u društvu, još uvijek ne dovodi to većeg preokreta u funkcioniraju ekonomije na održiviji način.

Može se reći da se neke ideje koje zagovara odrast testiraju (UTD), neke bore za mjesto (poput socijalne ekonomije), a neke tek trebaju dodatno osmisliti, poput revolucije skrbi. No, kao i cjelokupni pokret, odrast nam nudi alternativu u svijetu u kojem je 
promišljanje alternativa nužno. $\mathrm{Na}$ to upozoravaju čak i oni kojima trenutni načini funkcioniranja ekonomije i društveni odnosi najviše odgovaraju, poput velikih američkih korporacija koje najavljuju preobrazbu u „humaniju“ ekonomiju (Business Roundtable, 2020).

Kriza socijalne države prema Taylor-Goobyju (2005) uključuje tri dimenzije: širenje zahtjeva zbog transformacija suvremenog društva te pojave ranije objašnjenih novih socijalnih rizika, ograničenost resursa da se podmire ti zahtjevi te ograničenja vlade da izađu u susret s prvim dvjema dimenzijama, a koji su definirani radi postizanja tržišne konkurentnosti. Stanovnici EU strahuju za svoje potomstvo kojima će, zaključuju, biti teže nego što je bilo njihovoj generaciji (Dennison i sur., 2019). Ovakvi strahovi u vezi su s promjenama koje pogađaju socijalnu državu, a koje se događaju unatoč visokoj razini potpore (Europsko društveno istraživanje, 2018). S obzirom na spori, radno ne-intenzivan ekonomski rast, slabi porast stope zaposlenosti, povećanje troškova za socijalna davanja, demografske promjene i strah od strukturalnih promjena uzrokovanih novim informacijskim tehnologijama koja dovodi do sve većeg smanjivanja dostupnih poslova, sve se više propituje uspješnost starih oblika socijalne zaštite (McGahey, 2018:316). Dodajući tome već spomenutu polarizaciju u prihodima koja sve više raste, širenje prekarijata koji karakterizira kontinuirana radna nesigurnost te česti izlasci iz tržišta rada uz slabu dostupnost socijalne zaštite i lošu radnu zaštitu, trenutačno se propitkuje koliko je uređenje socijalne zaštite adekvatno za rješavanje problema s kojima se većina stanovništva danas nosi (Van Parijs i Vanderborght, 2017).

Kontinuirana težnja prema ekonomskom rastu ostavlja posljedice, kako na ekologiju, tako i na društvo i socijalnu politiku onemogućavajući joj da ispuni svoj puni potencijal. Socijalna se politika prema autorima treba definirati kao profesija usmjerena na specifične ciljeve poput iskorjenjivanja siromaštva, ostvarivanja dobrog zdravlja, stvaranja jednakih mogućnosti u obrazovanju, ostvarivanje dostojanstvenog stanovanja za sve, sprječavanje bilo kakve vrste diskriminacije te promoviranje socijalne uključenosti (Sen, 1999; Nussbaum, 2000; Rawls, 1972, prema Piachaud, 2015). Premda socijalne službe jesu važne u ostvarivanju definiranih ciljeva, važna je i uloga ekonomije, obiteljske razine te zajednice koje tek kombinirajući zajedno mogu postići ostvarenje cilja (Piachaud, 2015).

$S$ druge strane uzimajući u obzir i predviđanja o pojavi novih socijalnih rizika uzrokovanih klimatskim promjenama koji će, osim stvaranja dodatnih zahtjeva na socijalnu državu, svakako prouzročiti i nove troškove i dileme vraćajući paralelno staru raspravu o ulozi države u društvu, trenutačni status quo ${ }^{22}$ ekonomske dimenzije pa i njezinih posljedica na socijalnu razinu, vjerojatno će se promijeniti. Iako klimatske promjene imaju

22 Uzimajući u obzir da politike odrasta posljedično mijenjaju strukturu društva, za očekivati je javljanje izrazito jakog političkog otpora prema promjenama. U tom smislu potrebno je detaljnije analizirati odnos glasača, interesnih skupina, političara i državne uprave od koje svatko od aktera i sudionika podrazumijeva svoje ciljeve i interese, a samim time i potencijalne prepreke u prijelazu na novo društvo (Strunz i Schindler, 2017). 
mogućnost doprinijeti percepciji važnosti uloge države u društvu, one također imaju kapacitet odvratiti javne politike od socijalne dimenzije zanemarujući pitanja poput socijalne nejednakosti. Iz toga razloga zagovara se ekonomsko-socijalno-ekološki model odgovora na trenutačne i buduće izazove socijalne države koji uključuje sinergiju, kako socijalnih, tako i klimatskih politika (Gough, 2010; Bailey, 2015; Koch i sur., 2017) uključujući sve veće zalaganje za održivu socijalnu politiku čiji principi distribucije trebaju uključivati podmirivanje trenutačnih ljudskih potreba, ali i brigu o potrebama budućih generacijama (Hirvilammi i Koch, 2020). Takvim politikama pripada i pokret odrast.

\section{ZAKLJUČAK: NOVA VREMENA, NOVA RJEŠENJA?}

Socijalna država kakvu zagovara ideja odrasta podosta je različita od one stare u kojoj prevladavaju tradicionalni sustavi socijalne zaštite usmjereni na kompenzacijske programe. No, nova socijalna država razlikuje se i od zagovaranog koncepta socijalnih ulaganja, iako i s njom obuhvaća neke poveznice. U domeni socijalne zaštite, uz postojeće programe, ideja odrasta zagovara univerzalni temeljni dohodak, odnosno univerzalnu zaštitu svih stanovnika od siromaštva i socijalne nejednakosti. U domeni obiteljske, obrazovne, zdravstvene politike i socijalne skrbi ideja zagovara veći naglasak na kvaliteti i dostupnosti usluga stanovnicima, jačanje položaja svih aktera uključenih u proces odlučivanja o takvoj skrbi i stavljanje većeg naglaska na važnost i zaštitu skrbi u društvu. $\mathrm{Na}$ razini kombinirane socijalne politike naglasak se stavlja na one ekonomske procese koji podupiru održive socijalne i ekološke ciljeve kreirajući dobrobit za društvo u cjelini. $S$ obzirom na spomenute ideje, ovakva socijalna država kombinira postojeće, tradicionalne i kompenzacijske programe poput zdravstva, socijalne skrbi i obrazovanja i stavlja na njih veći naglasak, dok ih istovremeno kombinira $s$ aktivnim i prevencijskim programima socijalne države poput UTD-a i aktivnih politika na tržištu rada koje trebaju podupirati razvoj socijalne solidarne ekonomije. U odnosu prema konceptu socijalnog ulaganja, ona ide korak dalje te odbacuje produktivnost i važnost ekonomskih pokazatelja kao okvira za njezin daljnji razvoj, već prioritet stavlja na socijalne vrijednosti i kvalitetu života ljudi, odnosno prioritet stavlja na dobar život i blagostanje stanovnika u zajednici.

Socijalni programi koji pružaju zaštitu od novih socijalnih rizika još su uvijek u fazi razvoja u europskom prostoru, međutim to pitanje sve više dolazi u središte javnih rasprava (Bonoli, 2005:446). S druge strane socijalni rizici postali su više heterogeni i uslijed toga sve manje predvidivi. Ekonomska je kriza koja je zadnjih godina prisutna u Europi $^{23}$ također potakla brojne rasprave o traženju novih putova, kreiranju novih pri-

$23 \mathrm{Rad}$ je pisan ponajviše iz perspektive Europe i njezinih socijalnih država te dijelom predstavlja eurocentričnu perspektivu. No, unatoč tome smatramo da rad poziva na promišljanje novih tipova odgovora i testiranje novih rješenja koja mogu pokazati potencijal da budu univerzalna. Dakako, Europa je daleko od jedinstvene, posebno uzimajući u obzir razlike između centra i periferije. Te razlike postale su ujedno i središnje obilježje prethodne ekonomske krize (Becker i Jäger, 2011) te i dalje predstavljaju bitan aspekt 
stupa i koncepata socijalnih i ekonomskih politika (Crouch, 2011). ${ }^{24}$ Iako ideje odrasta podosta odudaraju od trenutačnog usmjerenja socijalne države, pojedine ideje odrasta polako ulaze u javne rasprave, ${ }^{25}$ dok se EU kao i druge, za EU važne međunarodne organizacije sve više okreću propitivanju socijalnih vrijednosti, bilo kroz razvoj različitih alternativnih metoda mjerenja razvoja, bilo kroz definiranje politika usmjerenih na socijalne ciljeve koje u tom opsegu do sada nikada nisu postojale. Za promjene je, prema održivoj socijalnoj politici, potreban uvjerljiv (i privlačan) narativ koji objašnjava kako podmiriti ljudske potrebe u ekološkim granicama te financirati socijalnu skrb (Hirvilammi, 2020).

Također, kada pogled usmjerimo prema generacijama koje dolaze ova se pitanja čine još značajnijima. Apeli mladih utjelovljeni primjerice u Štrajku za klimu kojem je zaštitno lice Greta Thunberg pozivaju na hitne akcije usmjerene na budućnost. Mladi se sve jasnije zalažu za održivi razvoj. Također pokazuju određenu orijentaciju prema redistribuciji bogatstva i smanjenju društvenih nejednakosti (Nico, 2019) ${ }^{26}$ Rad stoga nije empirijski utemeljeni poziv na implementaciju već prokušanih ideja. On je pledoaje odrasta, koji je prošao put od aktivističkog slogana do socijalnog pokreta koji nudi određene alternative i prijedloge za reforme (Demaria i sur., 2013) kako bi se otvorio prostor za rasprave i eksperimentiranje s novim rješenjima. Trenutne okolnosti pozivaju na socijalne inovacije koje će imati potencijal da donesu nove putove $\mathrm{k}$ budućem društvu obilježenog održivim razvojem i socijalnom državom koja može osigurati blagostanje u izmijenjenim ekonomskim i društvenim uvjetima. Ovo držimo tek početkom razgovora koji će se neminovno nastaviti u budućnosti.

razlikovanja država Europe u političkoj moći i ekonomskim resursima. Primjer toga su i ideje integracije Europe u „dvije brzine“ koje naglašavaju jaz između centra i periferije Europe. Ekonomska divergencija ne prati uvijek onu političku (Börzel i Langbein, 2019) te razlike među zemljama mogu biti bitan faktor za prihvaćanje ideja odrasta, a koji upravo kao jedan od ciljeva želi djelovati na njihovom umanjivanju.

24 Čak i tvrtke gledaju s promijenjenim pogledom na svoju odgovornost i ulogu u društvu, čemu je primjer i posljednji manifest svjetskog ekonomskog foruma u Davosu (Schwab, 2019).

25 Vidi primjerice odgovor Europske komisije na pitanje o perspektivi prema UTD-u na stranici Europskog parlamenta (Thyssen, 2019) ili pak potporu razvoju socijalne ekonomije: „The promotion of the social economy as a key driver of economic and social development in Europe" (Vijeće EU, 2015).

26 Kada pogledamo primjerice stavove prema principima odrasta u Hrvatskoj pokazuje se da Hrvati pokazuju povećanu svijest o rizicima poput degradacije okoliša te snažnije sklonosti preraspodjeli materijalnog bogatstva (Domazet, 2019). 


\section{LITERATURA}

Alliance of World Scientists (2020). URL: https://scientistswarning.forestry.oregonstate.edu/ (01.02.2020.)

Anttonen, A. i Haïkiö, L. (2011). Care 'going market': Finnish elderly-care policies in transition. Nordic Journal of Social Research, 2: 70-90.

Armstrong, K., A. (2012). EU social policy and the governance architecture of Europe 2020. Transfer: European Review of Labour and Research, 18(3): 285-300.

Babić, Z. i Baturina, D. (2016). Koncept socijalnih investicija kao odgovor na krizu i nove izazove socijalne države: trendovi i perspektive. Revija za socijalnu politiku, 23(1): 39-60.

Bailey, D. (2015). The Environmental Paradox of the Welfare State: The Dynamics of Sustainability. New Political Economy, 20(6): 793-811.

Becker, J. i Jäger, J. (2011). European Integration in Crisis: the Centre-Periphery Divide. $17^{\text {th }}$ Euromemo Workshop on Alternative Economic Policy. Beč, 16.-18. rujna 2011.

Bežovan, G. (2008). Civilno društvo i kombinirana socijalna politika. U: Puljiz, V. Bežovan, G., Matković, T., Šućur, Z. i Zrinščak, S. (ur.), Socijalna politika Hrvatske. Zagreb: Pravni fakultet Sveučilišta u Zagrebu.

Bežovan, G. i Zrinščak, S. (2001). Mogućnosti decentralizacije u socijalnoj politici i nove uloge lokalnih vlasti. Revija za socijalnu politiku, 8(3-4): 239-258.

Blaschke, R. (2017). Unconditional Basic Income: Sustainable Ecological Transition is Impossible Without Ununconditional Social Security for All People. Degrowth in movement(s), 24. siječnja 2017. URL: https://www.degrowth.info/en/dim/degrowth- in-movements/unconditional-basic-income/ (02.08.2019.)

Blauwhof, F. B. (2012). Overcoming accumulation: Is a capitalist steady-state economy possible? Ecological Economics, 84: 254-261.

Bonoli, G. (2005). The politics of the new social policies. Providing coverage against new social risks in mature welfare states. Policy and Politics, 33(3): 431-449.

Bornstein, D. (2004). How to Change the World. Social Entrepreneurs and the Power of New Ideas. Oxford: Oxford University Press.

Borzaga, C. i Defourny, J. (ur.) (2001). The Emergence of Social Enterprise. London: Routledge.

Börzel, T. A. i Langbein, J. (2019) Core-periphery disparities in Europe: is there a link between political and economic divergence? West European Politics, 42(5): 941-964.

Bovaird, T., Van Ryzin, G. G., Loeffler, E. i Parrado, S. (2015). Activating Citizens to Participate in Collective Co-Production of Public Services. Journal of Social Policy, 44(1): 1-23.

Braconier, H., Nicoletti, G. i Westmore, B. (2014) Policy challenges for the next 50 years. OECD Economic Policy Paper, br. 9. Pariz: OECD Publishing.

Brennan, D., Cass, B., Himmelweit, S. i Szebehely (2012). The marketisation of care: Rationales and consequences in Nordic and liberal care regimes. Journal of European Social Policy, 22(4): 377-391. 
Business Roundtable (2020). Statement on the Purpose of a Corporation. URL: https:// opportunity.businessroundtable.org/ourcommitment/ (01.02.2020.)

Cantillon, B. (2010). Disambiguating Lisbon. Growth, Employment and Social Inclusion in the Investment State. Centre for Social Policy Working paper, br. 10/07. Antwerpen: Herman Deleeck Centre for Social Policy.

Chaves, R. i Monzón, J. L. (2012). Beyond the crisis: the social economy, prop of a new model of sustainable economic development. Service Business, 6(1): 5-26.

Crouch, C. (2011). The Strange Non-Death of Neoliberalism. Cambridge: Polity Press.

D`Alissa, G., Demaria F. i Kallis, G. (2016). Odrast. Pojmovnik za novu eru. Zagreb: Fraktura i Institut za političku ekologiju.

Demaria, F., Schneider, D., Sekulova, F. i Martinez-Alier, J. (2013). What is Degrowth? From an Activist Slogan to a Social Movement. Environmental Values, 22(2): 191215.

Defourny, J. i Nyssens, M. (2010). Conceptions of social enterprises and social enterpreneurship in Europe and in the United States; convergences and divergences. Journal of social enterpreneurship, 1(1): 32-53.

Dennison, S., Leonard, M. i Lury, A. (2019). What Europeans really feel: The battle for the political system. European Council on Foreign Relations, 16. svibnja 2019. URL: https://ecfr.eu/publication/what_europeans_really_feel_the_battle_for_the_political_sy stem_eu_election/ (01.02.2020.)

Department for International Development (2008). Growth: Building jobs and prosperity in developing countries. URL: https:/www.oecd.org/derec/unitedkingdom/40700982.pdf (10.07.2019.)

Domazet, M. (2019). Degrowth-compatible Common Senses in Croatia. Südosteuropa Mitteilungen, 59(5-6): 158-168.

Duffy, S. (2010). The Future of Personalisation. Journal of Care Services Management, 4(3): 202-216.

Egger, D., Haushofer, J., Miguel, E., Niehaus, P. i Walker, M. (2019). General equilibrium effects of cash transfers: experimental evidence from Kenya. National Bureau of Economic Research Working Papers, 26600. Cambridge, MA: National Bureau of Economic Research.

Esping-Andersen, G. (2002). Why We Need a New Welfare State. Oxford: Oxford University Press.

Europsko društveno istraživanje (2018). The Past, Present and Future of European Welfare Attitudes: Topline Results from Round 8 of the European Social Survey. ESS Topline Series, br. 8. London: Europsko društveno istraživanje.

Europski gospodarski i socijalni odbor (2017). Najnovija kretanja u okviru socijalne ekonomije u Europskoj uniji. Bruxelles: Europski gospodarski i socijalni odbor. URL: https:// www.eesc.europa.eu/sites/default/files/files/qe-04-17-876-hr-n.pdf (03.08.2019.)

Europska komisija (1994). Growth, competitiveness, employment: The challenges and ways forward into the 21st century. White paper. Luxembourg: Office for Official Publications of the European Communities. Bruxelles: Europska komisija. URL: https:// 
op.europa.eu/en/publication-detail/-/publication/4e6ecfb6-471e-4108-9c7d-90cb1c3096af/language-en (30.08.2019.)

Europska komisija (2003). The future of the European Employment Strategy (EES): „A Strategy for Full Employment and Better Jobs for All“. Priopćenje komisije, COM (2003) 6, Bruxelles, 14. siječnja 2003. URL: https://eur-lex.europa.eu/legal- content/ EN/TXT/?uri=CELEX\%3A52003DC0006 (30.08.2019.)

Europska komisija (2013). Paket socijalnog ulaganja EU-a. Priopíenje komisije, COM (2013) 83, Bruxelles, 20. veljače 2013. URL: https://eur-lex.europa.eu/legal- content/HR/TXT/?uri=celex\%3A52013DC0083 (30.08.2019.)

Europska komisija (2014). A map of social enterprises and their eco-systems in Europe. Synthesis Report. London: ICF Consulting Services Limited. URL: https://ec.europa.eu/social/BlobServlet?docId=12987\&langId=en (01.02.2020.)

Europska komisija, (2019a). Zapošljavanje, socijalna pitanja i uključenost. URL: https://ec.europa.eu/social/main.jsp?langId=hr\&catId=750 (30.08.2019.)

Europska komisija (2019b). Joint Report on Health Care and Long-Term Care Systems \& Fiscal Sustainability: Country Documents 2019 Update. European Economy Institutional Papers, br. 105. Bruxelles: Europska komisija.

Europski parlament (2000). Lisbon European Council 23 and 24 March 2000: Presidency Conclusions. URL: http://www.europarl.europa.eu/summits/lis1_en.htm (05.06.2019.)

Eurostat (2015). Being young in Europe today. Bruxelles: Europska komisija. URL: https://www.west-info.eu/how-many-children-live-in-the- european-union/18bee6f0- c181-457d-ba82-d77b314456b9/ (30.08.2019.)

Eurostat (2019a). Disability statistics - need for assistance. URL: https://ec.europa.eu/ eurostat/statisticsexplained/index.php?title=Disabilitystatistics_need_for_assistance\&oldid=433462\#People_with_disabilities_requiring_assist ance (30.08.2019.)

Eurostat (2019b). Reconciliation between work and family life: 1 in 3 people in the EU reported care responsibilities in 2018. Newsrelease, 154. URL: https://ec.europa. eu/eurostat/documents/2995521/10157119/3-10102019-AP- EN.pdf/182bca6f3e23-c913-0dcf-b25f846fa1 e2 (21.03.2019.)

Ferguson, P. (2018). Post-growth Politics. A critical Theoretical an Policy Framework for Decarbonisation. Cham: Springer.

Ferrera, M. (2005). The Boundaries of Welfare: European Integration and the New Spatial Politics of Social Solidarity. Oxford: Oxford University Press.

Ferrera, M., Matsaganis, M. i Sacchi, S. (2004). Model otvorene koordinacije protiv siromaštva: Novi „proces socijalnog uključivanja“ Europske unije. Revija za socijalnu politiku, 11(3-4): 395-409.

Forget, E. L. (2011). The Town with No Poverty: The Health Effects of a Canadian Guaranteed Annual Income Field Experiment. Canadian Public Policy, 37(3): 283- 305.

Frajman Ivković, A. (2012). Progres društva vođen subjektivnim blagostanjem: indeks sreće građana. Doktorska disertacija. Osijek: Ekonomski fakultet u Osijeku. 
Frey, B., C. i Osborne, M. A. (2013). The Future of Employment: How Susceptible Are Jobs to Computerisation? Oxford: Oxford Martin Programme on Technology and Employment.

Galić, B. (2011). Žene i rad u suvremenom društvu - značaj „orodnjenog“ rada. Sociologija i prostor, 49(1): 25-48.

Garben, S. (2018). The European Pillar of Social Rights: Effectively Addressing Displacement? Constitutional Law Review, 14(1): 210-230.

Gough, I. (2010). Economic crisis, climate change and the future of welfare states. Twenty-First Century Society, 5(1): 51-64.

Hemerijck, A. (2013). Changing welfare states. Oxford: Oxford University Press.

Hirvilammi, T. (2020) The Virtuous Circle of Sustainable Welfare as a Transformative Policy Idea. Sustainability, 12(1): 391-406.

Hirvilammi, T. i Koch, M. (2020). Sustainable Welfare beyond Growth. Sustainability, 12(5): 1824-1832.

Jackson, T (2017). Prosperity Without Growth: Foundation for the economy of tomorrow. Second Edition. London: Routledge.

Kangas, O., Jauhiainen, S., Simanainen, M. i Ylikännö, M. (2019). The basic income experiment 2017-2018 in Finland. Preliminary results. Helsinki: Ministry of Social Affairs and Health.

Klitgaard, K. (2013). Heterodox Political Economy and the Degrowth Perspective. Sustainability 5(1): 276-297.

Koch, M., Buch-Hansen, H. i Fritz, M. (2017). Shifting priorities in degrowth research: An argument for the centrality of human needs. Ecological Economics, 138: 74-81.

Latouche, S. (2010). Degrowth. Journal of Cleaner Production, 18(6): 519-522.

Lawn, P. (2011). Is steady-state capitalism viable? A review of the issues and an answer in the affirmative. Annals of the New York Academy of Sciences, 1219(1): 1-25. DOI: 10.1111/j.1749-6632.2011.05966.x.

Lietaert, M. (2010) Cohousing's relevance to degrowth theories. Journal of Cleaner Production, 18(6): 576-580.

Matsui, N. i Ikemoto, Y. (2015). Solidarity Economy and Social Business: New Models for a New Society. Tokyo: Springer.

McGahey, R. (2018). Universal Basic Income and the Welfare State. U: Ocampo, J. A. i Stiglitz, J. E. (ur.), The Welfare State Revisited (str. 316-336). New York, NY: Columbia University Press.

Međunarodna organizacija rada (2004). World Commission on the Social Dimension of Globalization - The Social Dimension of Globalization. URL: https://www.ilo. org/public/english/wcsdg/globali/globali.htm (09.09.2020.)

Međunarodna organizacija rada (2018). Care work and care jobs for the future of decent work. Geneva: Međunarodna organizacija rada.

Mencinger, J. (2015). The Revenue Side of a Universal Basic Income in the EU and Euro Area. Law and Economics Review, 6(3): 159-174. 
Meštrović, M. i Cvijanović, V. (2007). Prikaz nekih kritika neoklasične škole ekonomskog mišljenja. Zbornik Ekonomskog fakulteta u Zagrebu, 5(1): 439-446.

Milanović, B. (2016). Global Inequality: A New Approach for the Age of Globalization. Cambridge, MA: Harvard University Press.

Monzón, J. L. i Chaves, R. (2010). Socijalna ekonomija u Europskoj uniji. Revija za socijalnu politiku, 17(1): 113-138.

Neamtan, N. (2009). Social Economy: Concepts and Challenges. Universitas Forum: International Journal on Human Development and International Cooperation, 1(3): 1-5. URL: http://universitasforum.org/index.php/ojs/article/view/31 (27.07.2019.)

Nedelkoska, Lj. i Quintini, G. (2018). Automation, skills use and training. OECD Social, Employment and Migration Working Papers, br. 202. Pariz: OECD Publishing.

Neumann, M. i Winker, G. (2016). Care revolution: Fighting for Care Work Resources. Degrowth in movement(s), 13. prosinca 2016. https://www.degrowth.info/en/ $\mathrm{dim} /$ degrowth-in-movements/care-revolution/ (10.08.2019.)

Nicholls, A. (ur.) (2006). Social Entrepreneurship - New Models of Sustainable Social Change. Oxford: Oxford University Press.

Nico, M. (2019). What do I care for? Social Values of Young People Compared. Youth Partnership URL: https://pjp- eu.coe.int/documents/42128013/47262649/Socia1+Values+full+paper.pdf/c8e7b81a- f41b-52ca-ea31-7e7e5c4ce67f (01.02.2020.)

Noruzi, M. R., Westover, J. H. i Reza Rahimi, G. (2010). An Exploration of Social Entrepreneurship in the Entrepreneurship Era. Asian Social Science, 6(6): 3-10.

OECD - Organizacija za ekonomsku suradnju i razvoj (2011). Together for better public services. Partnering with citizens and civil society. Pariz: OECD Publishing.

Oláh L. S., Kotowska I. E. i Richter R. (2018). The New Roles of Men and Women and Implications for Families and Societies. U: Doblhammer G. i Gumà J. (ur.), $A$ Demographic Perspective on Gender, Family and Health in Europe (str. 41-64). Cham: Springer.

Parrique, T. (2019). The political economy of degrowth. Doktorska disertacija. Stockholm: Stockholm University, Stockholm Resilience Centre.

Piachaud, D. (2015). The Future of Social Policy-Changing the Paradigm. Asia \& the Pacific Policy Studies, 2(1): 1-7.

Pierson, P. (2001). The new politics of welfare state. Oxford: Oxford University Press.

Piketty, T. (2014). Kapital u 21. stoljeću. Zagreb: Profil.

Poirer, Y. (2014). Social Solidarity Economy and related concepts. Origins and Definition: An International Perspective. URL: https://base.socioeco.org/docs/solidarity_economy_and_other_concepts-poirier-july-2015.pdf (03.08.2019.)

Puljiz, V. (2008). Socijalna politika Hrvatske. Zagreb: Pravni fakultet.

Research and Degrowth (2010). Degrowth Declaration of the Paris 2008 conference. Journal of Cleaner Production, 18(6): 523-524.

RIPESS - Europska mreža za solidarnu ekonomiju (2015). Global Vision for a Social Solidarity Economy: Convergences and Differences in Concepts, Definitions and Frameworks. URL: http://www.ripess.org/wp- content/uploads/2017/08/RIPESS_Vision-Global_EN.pdf (27.07.2019.) 
Ripple, J. W., Wolf, C., Newsome, T. M., Barnard, P. i Moomaw, W. R. (2019). World Scientists' Warning of a Climate Emergency. BioScience, 70(1): 8-12.

Samuelson, P. A. i Nordhaus, W. D. (1992). Ekonomija. Zagreb: MATE.

Schneider, F. (2010). Crisis or opportunity? Economic degrowth for social equity and ecological sustainability. Introduction to this special issue. Journal of Cleaner Production, 18(6): 511-518.

Schwab, K. (2019). Davos Manifesto 2020: The Universal Purpose of a Company in the Fourth Industrial Revolution. World economic forum, 2. prosinca 2019. URL: https://www.weforum.org/agenda/2019/12/davos-manifesto-2020-the-universalpurpose-of-a-company-in-the-fourth-industrial-revolution/ (10.02.2020.)

Social Care Institute for Excellence (2012). Personalisation - making it happen: the social worker's perspective. URL: https://www.scie.org.uk/personalisation/practice/ social- workers/making-it-happen (20.1.2020.)

Social Protection Committee (2009). Growth, Jobs and Social Progress in the EU: A Contribution to the Evaluation of the Social Dimension of the Lisbon Strategy. Bruxelles: Europska komisija. URL: https://ec.europa.eu/social/BlobServlet?docId $=14239$ \&langId $=$ en (30.08.2019.)

Sorman, A. H. i Giampietro, M. (2013). The energetic metabolism of societies and the degrowth paradigm: analyzing biophysical constraints and realities. Journal of Cleaner Production, 38(13): 80-93.

Spangenberg, J. H. (2010). The growth discourse, growth policy and sustainable development: two thought experiments. Journal of Cleaner Production, 18(6): 561- 566.

Stiglitz, J. E., Sen, A. i Fitoussi, J. (2009). Report by the Commission on the Measurement of Economic Performance and Social Progress. Pariz: Commission on the Measurement of Economic Performance and Social Progress. URL: https://www. economie.gouv.fr/files/finances/presse/dossiers_de_presse/090914mesure _perf_ eco_progres_social/synthese_ang.pdf (20.07.2019.)

Strunz, S. i Schindler, H. (2017). Identifying barriers towards a post-growth economy: A political economy view. Ecological Economics, 153: 68-77.

Svjetska banka (2019). World Development Report 2019: The Changing Nature of Work. Washington, DC: Svjetska banka.

Taylor-Gooby, P. (2005). New Risk, New Welfare: The transformation of the European Welfare State. Oxford: Oxford Scholarship Online.

Taylor-Gooby, P., Leruth, B. i H. Chung, H. (ur.) (2017). After austerity: Welfare state transformation in Europe after the Great Recession. Oxford: Oxford University Press.

Thyssen, M. (2019). Answer given by Ms Thyssen on behalf of the European Commission. Parliamentary questions, E-001465/2019, 18. lipnja 2019. URL: https:// www.europarl.europa.eu/doceo/document/E-8-2019-001465-ASW_EN.html (01.02.2020.)

Todaro, M. P. i Smith, S. C. (2006). Ekonomski razvoj. Varaždin: TKD Šahinpašić. Van den Bergh, J. C. J. M. (2009). The GDP paradox. Journal of Economic Psychology, 30(2): 117-135. 
Vandenbroucke, F. i Vleminckx, K. (2011). Disappointing poverty trends: Is the social investment state to blame. Journal of European Social Policy. 21(5): 450-471.

Van Parijs, P. i Vanderborght, Y. (2017). Basic Income: A Radical Proposal for a Free Society and a Sane Economy. Cambridge, MA: Harvard University Press.

Verdun, A. i Zeitlin, J. (2018). Introduction: the European Semester as a new architecture of EU socioeconomic governance in theory and practice. Journal of European Public Policy, 25(2): 137-148.

Vijeće Europske unije (1997). Uredba Vijeća br. 1466/97 od 7. srpnja 1997. o jačanju nadzora stanja proračuna i nadzora i koordinacije ekonomskih politika. Službeni list Europske unije, 10(3): 27-31.

Vijeće Europske unije (2015). The promotion of the social economy as a key driver of economic and social development in Europe. Zaključak vijeća, 15071/15 SOC 711 EMPL 464 URL: https://data.consilium.europa.eu/doc/document/ST-150712015- INIT/en/pdf (01.02.2020.)

Voorberg, W. H., Bekkers, V. J. J. M. i Tummers, L. G. (2015). A Systematic Review of Co-Creation and Co-Production: Embarking on the social innovation journey. Public Management Review, 17(9): 1333-1357.

Winker, G. (2015). Care Revolution: A Feminist-Marxist Transformation Strategy from the Perspective of Caring for Each Other. U: Baier, W., Canepa, E. i Himmelstoss, E. (ur.): transform! Yearbook 2016: The Enigma of Europe (str. 165-172). London: Merlin Press.

Womankind Worldwide (2019). Working towards a just feminist economy: The role of decent work, public services, progressive taxation and corporate accountability in achieving women's rights. London: Womankind Worldwide. URL: https:// world-psi.org/uncsw/wordpress/wp-content/uploads/2019/03/working- towardsa-just-feminist-economy-final-web.pdf (01.09.2019.)

Wright, E. O. (2002). Basic Income, Stakeholder Grants, and Class Analysis. Real Utopias conference on "Rethinking Redistribution". Madison, WI, 1. srpnja 2002. URL: https://www.ssc.wisc.edu/ - wright/EOW\%20RR\%20essay.pdf (10.08.2019.) 


\title{
WHAT DOES OUR FUTURE HOLD? DEGROWTH AND THE POTENTIAL FOR SOCIAL POLICY TRANSFORMATION
}

\author{
Mirela Matković and Danijel Baturina
}

\begin{abstract}
Modern government policies are limited by prioritizing economic growth, a strategy that is being increasingly questioned as it is not clear whether it really contributes to the development of personal wellbeing. New theories in professional and public debated are proposing the limits to economic growth, especially with regards to climate change. These new ideas have also been increasingly influencing policies at the international level, directing them more toward such concepts as sustainable development. The welfare state faces several challenges, to which it lacks adequate response, and which stand in the way of implementing new approaches: globalization, the emergence of new social risks, the heavy financial burdens of old social programs, the European Union, with its fears and political inertia, the rise of anti-European tendencies, and the emphasis on the politics of the single market and the stability of public finances. Thinking about growth outside the usual framework, by putting emphasis on sustainable development, as advocated by the degrowth movement, which we present in this paper, can potentially lead to the development of new strategies and social innovations in existing social politics, more in line with the degrowth principles. This paper analyzes several aspects of social policies that can potentially be transformed through the perspective of degrowth: the basic universal income, the revolutionizing the care system, and the social (and solidarity) economy. We discuss how these new ideas and strategies can become solutions to the existing challenges facing contemporary societies and their social policies. Degrowth opens up the space for new solutions that can potentially lead to sustainable social policies and fulfilling human needs, which we discuss in the conclusion.
\end{abstract}

Keywords: degrowth, social state, social policies

\section{DIE ZUKUNFT VOR UNS? WACHSTUMSRÜCKNAHME UND MÖGLICHKEIT DER ÄNDERUNG DER SOZIALEN POLITIK}

\author{
Mirela Matković und Danijel Baturina
}

\begin{abstract}
Zusammenfassung
Zeitgenössische Staatspolitiken sind durch die Priorität des ökonomischen Wachstums begrenzt, man stellt sich aber immer wieder die Frage, ob es dem persönlichen Wohlstand beiträgt. In fachlichen und öffentlichen Diskussionen wird immer öfter über die Grenzen des ökonomischen Wachstums gesprochen, insbesondere hinsichtlich des Klimawandels. Solche Erkenntnisse bilden neue Bewegungen auf der internationalen Ebene und steuern die Politiken immer mehr in Richtung der Idee der nachhaltigen Entwicklung. In der Domäne des sozialen Staates sind neue Richtungen durch Herausforderungen bestimmt, die mit Prozessen gleichgestellt werden wie: Globalisierung, neue soziale Risiken, hohe finanzielle Belastung, alte soziale Programme, Europäische Union, Ängste und politische Trägheit, sowie Unterstützung von antieuropäischen Strömungen, aber auch die Priorität der Politiken des einheitlichen Marktes und der Stabilität von öffentlichen Finanzen, als deren Folge es an einer adäquaten Antwort auf bestehende Herausforderungen des sozialen Staates mangelt. Wenn man außer dem üblichen Rahmen des Wachstums die Nachaltigkeit überlegt, so wie es die Bewegung der Wachstumsrücknahme befürwortet, die wir in dieser Arbeit vorstellen, entsteht in der sozialen Politik Raum für die Entwicklung neuer Strategien und sozialer Innovationen gemäß Prinzipien der Wachstumsrücknahme. Das Ziel dieser Arbeit ist es, mögliche Ideen aus der Perspektive der Wachstumsrücknahme zu erkennen, die die soziale Politik transformieren können. Die Arbeit analysiert eionige Ideen: ein universelles Grundeinkommen, eine Pflegerevolution und eine soziale (und solidarische) Ökonomie. Die Diskussion prüft die Art und Weise, wie neugebildete Ideen und Strategien Lösungen für
\end{abstract}


bestehende Herausforderungen anbieten können, mit denen sich die zeitgenössische Gesellschaft und die soziale Politik konfrontieren. Die Überlegung der Wachstumsrücknahme bietet Raum für neue Lösungen, die möglicherweise zu nachahltigen sozialen Politiken und Befriedigung von menschlichen Bedürfnissen führen können, was wir im Schluss berücksichtigen.

Schlüsselwörter: Wachstumsrücknahme, sozialer Staat, soziale Politik 